NBER WORKING PAPER SERIES

\title{
DO FLEXIBLE DURABLE GOODS PRICES \\ UNDERMINE STICKY PRICE MODELS?
}

Robert Barsky

Christopher L. House

Miles Kimball

Working Paper 9832

http://www.nber.org/papers/w9832

\author{
NATIONAL BUREAU OF ECONOMIC RESEARCH \\ 1050 Massachusetts Avenue \\ Cambridge, MA 02138 \\ July 2003
}

The views expressed herein are those of the authors and not necessarily those of the National Bureau of Economic Research

C2003 by Robert Barsky, Christopher L. House, and Miles Kimball. All rights reserved. Short sections of text not to exceed two paragraphs, may be quoted without explicit permission provided that full credit including (C) notice, is given to the source. 
Do Flexible Durable Goods Prices Undermine Sticky Price Models?

Robert Barsky, Christopher L. House, and Miles Kimball

NBER Working Paper No. 9832

July 2003

JEL No. E21, E30, E31, E32

\section{ABSTRACT}

Multi-sector sticky price models have surprising implications when durable goods have flexible prices. While in actual data the production of virtually all durables exhibits strong negative responses to monetary contractions, in dynamic general equilibrium models a monetary contraction causes the output of flexibly priced durables to expand. Indeed, in the polar case in which only nondurables have sticky prices, the negative comovement of durable and nondurable production exactly offsets and the behavior of aggregate output mimics that of a model with fully flexible prices. While this "neutrality" result is special, the "comovement problem" - the perverse response of flexibly priced durables to monetary policy shocks - is highly robust. When some durables prices are flexible and others sticky, the comovement problem still applies strongly to the subset of durables with flexible prices. We argue that new housing construction might be best characterized as a flexible price industry for which the comovement problem is relevant. The underlying reason for the comovement problem is the combination of a naturally high intertemporal elasticity of substitution for the purchases of durables and temporarily low marginal costs associated with economic contractions.

$\begin{array}{lll}\text { Robert Barsky } & \text { Christopher L. House } & \text { Miles Kimball } \\ \text { Department of Economics } & \text { Department of Economics } & \text { Department of Economics } \\ \text { University of Michigan } & \text { University of Michigan } & \text { University of Michigan } \\ \text { Ann Arbor, MI 49109-1220 } & \text { Ann Arbor, MI 49109-1220 } & \text { Ann Arbor, MI 49109-1220 } \\ \text { and NBER } & \text { chouse@umich.edu } & \begin{array}{l}\text { and NBER } \\ \text { kimball@umich.edu }\end{array}\end{array}$




\title{
Do Flexible Durable Goods Prices Undermine Sticky Price Models?
}

\author{
Robert Barsky \\ University of Michigan and NBER \\ Christopher L. House \\ University of Michigan \\ Miles Kimball \\ University of Michigan and NBER
}

June 17, 2003

\section{Introduction}

Modern theories of the monetary business cycle typically attribute central importance to nominal rigidities. Much of our understanding of the behavior of stickyprice models has come from one-sector models with symmetric firms using identical price-setting rules. In realistic economies, however, not all prices are equally sticky. For instance, the price of a bottle of Coca Cola was stuck at five cents for a period of 70 years. ${ }^{1}$ At the other extreme, the prices of many agricultural commodities vary daily. We will make the case that the pricing of newly constructed housing is better characterized as flexible than as sticky in the sense required for/by the logic of the modern sticky price model.

In addition to restricting their attention to models in which all prices are equally sticky, a surprising fraction of researchers focus on the behavior of nondurables alone. Yet in actual data, fluctuations in the production of durable goods are a prominent feature of the response to monetary shocks. For example, in the data, housing production falls sharply following a monetary contraction, while the production of nondurables falls very little.

\footnotetext{
${ }^{1}$ See Levy and Young [2002]
} 
This paper studies the equilibrium implications of the interaction between the degree of durability and the degree of price flexibility in a sector. In particular, we ask whether sticky price models can have sectors with flexible prices and still match the main features of the data. We analyze a model with both sticky price and flexible price sectors, and with both durable and nondurable goods. We find that it is not sufficient to specify how large the sticky price sector is relative to the flexible price sector; it matters crucially which sectors have sticky prices.

In particular, neoclassical sticky price models exhibit surprising behavior when augmented with durable goods with flexible prices. In these models there is a strong tendency for production of flexibly priced durables to expand during periods of tight money and contract during periods of monetary expansion. In an instructive special case in which the only sticky prices are those of nondurables, the negative comovement of durables and nondurables output entails exactly offsetting effects, and the behavior of aggregate output in the model is very similar to that of a model with fully flexible prices. While this neutrality result requires special circumstances, the perverse response of flexibly priced durables to monetary policy is highly robust.

What is special about durables? Purchases of nondurables are subject to the consumption smoothing logic of the permanent income hypothesis. As a result, there is relatively little room for consumers to substitute intertemporally in response to a change in the relative price of nondurables. On the other hand, the stock - and the associated shadow value - of durables is nearly constant over the modest horizon for which monetary disturbances might have real effects; the intertemporal elasticity of substitution for purchases of durables is nearly infinite. The result is that a small, temporary increase in the relative price of durables causes a large shift of expenditure away from that sector. ${ }^{2}$

Monetary expansions increase spending at constant prices, and typically result in increased output, increased factor demands, and higher marginal costs of production. To the extent that monetary expansions increase output and employment in equilibrium, the period following such an expansion is an expensive time to produce. While the markups on goods with sticky prices are squeezed below their desired levels, for producers in

\footnotetext{
${ }^{2}$ We have not formally studied the case of storable, though nondurable, consumption goods. It appears that at least some of the logic of this argument carries over to that case.
} 
flexible price sectors, the increase in factor prices is merely an adverse cost shock. Unless there is an offsetting endogenous increase in demand, flexible price sectors will contract. We show that there is little hope of generating such an increase in the demand for durables as a consequence of monetary expansion. This scenario contrasts sharply with the conventional view of durables in informal Keynesian models. Those models posit powerful forces that cause demand for durables to rise sharply following a monetary expansion, more than offsetting any contractionary effects of increased factor prices.

The mechanism that leads to the contrarian behavior of the durables sector in our scenario is a manifestation of a more general comovement problem discussed by Murphy, Shleifer, and Vishny [1989]. In multi-sector general equilibrium models, shocks that cause an expansion in one sector have a tendency to cause contractions in other sectors. For example, in a real business cycle model, temporary favorable technology shocks in the consumption sector also cause a contraction in the durables sector and tend not to raise aggregate output. The logic is essentially the same; temporary technology shocks are analogous to the temporary deviations in the markup (or "real marginal cost") in the sticky price model.

Our most important result is that if any long-lived durable has flexible prices, otherwise standard neoclassical sticky-price models generate negative comovement for that sector. This result is interesting regardless of its empirical relevance because it reveals the powerful implications of the inclusion of durables in dynamic models. Nevertheless, this line of inquiry is of even more compelling interest if there in fact exist economically significant long-lived durables that have flexible prices. We argue that housing is such a good. There is no question that residential housing is very durable the stock/flow ratio is roughly 55 to $1 .^{3}$ It is unlikely that contractors commit to prices prior to construction, suggesting that prices are not sticky at the critical point where the quantity of construction is decided. Finally, residential investment is a significant and volatile component of GDP. Fluctuations in residential investment account for $18.3 \%$ of the fluctuations in GDP. In comparison, the production of nonresidential structures,

\footnotetext{
${ }^{3}$ There are roughly 72 million owner occupied houses in the U.S. In 2000, there were 1.3 million housing starts of 1-4 unit dwellings.
} 
equipment and software, and changes in inventories account for 5.95\%,15.77\% and $16.92 \%$ of GDP fluctuations respectively. ${ }^{4}$

In fact, there are good reasons to believe that many durables have prices that are relatively flexible. First, as we demonstrate in the next section of this paper, the price of durables relative to that of nondurables falls in response to monetary contractions. Following a Romer date, the price of new houses falls by almost $10 \%$ relative to the CPI for nondurables. Automobile prices and the CPI for durable goods fall by roughly 5\% relative to the CPI for nondurables. Second, although it is well known that CPI inflation is positively serially correlated ("inflation persistence"), the degree of serial correlation is not equal across goods. Interestingly, the prices of new houses, in particular, do not exhibit any inflation persistence. Inflation in the median price of new housing displays negative serial correlation, indicating that these prices jump and indeed tend to overshoot.

In addition to these empirical findings, there are conceptual reasons to expect the transaction prices of many durables to be effectively flexible. One difference between durables and nondurables is that durable goods are relatively expensive on a per-unit basis. If the explicit and implicit costs of negotiation have an important fixed component, there is more incentive to negotiate on the price of a durable good (see also Leahy $[1995])^{5}$. Some durables are priced for the first time when they are sold. Other large durables often require considerable customization; this necessitates negotiations, and the discussions about the exact nature of the good are likely to be accompanied by negotiations about price. Zabracki, et al. [2002] present evidence obtained "in the field" on negotiations between large business customers and sales representatives of a large supplier of industrial durables. They show that salesmen do in fact have (and exercise) considerable leeway to offer "deals" to major customers who express dissatisfaction with increases in list price.

Previous papers that have studied models with flexible and sticky price sectors include Blinder and Mankiw [1984], Ohanian and Stockman [1994], Ohanian, Stockman, and Kilian [1995], and Bils, Klenow and Kryvstov [2003]. Only Ohanian et al. [1995]

\footnotetext{
${ }^{4}$ In 2000, residential investment accounted for 412 billion dollars - roughly 4\% of GDP. The standard deviation of employment in construction relative to trend is $3.75 \%$ compared with $1.47 \%$ for aggregate employment. The corresponding volatility for residential investment production is $10 \%$ compared with $1.66 \%$ for GDP.

${ }^{5}$ This logic, however, does apply as well to nondurables that are sold to retailers in large lots.
} 
includes a durables sector. The simulations Ohanian et. al present illustrate the comovement and neutrality problems we discuss below, but without a full explanation. The comment on Ohanian et al. by Leahy [1995] hints at some of the logic behind these effects, but leaves several questions unanswered - particularly why the overall output effect is so close to zero. Ohanian and Stockman [1994] allow for a variable intertemporal elasticity of substitution across two nondurable sectors. As we emphasize later, the naturally high intertemporal elasticity of substitution in durable goods spending plays a central role in our paper, and thus some of the economics in this paper parallels that in Ohanian and Stockman [1994].

The remainder of the paper is organized as follows. In Section 2 we present empirical results pertaining to durable goods sectors, paying particular attention to the housing industry. We first document that both the production and the relative price of durables fall sharply after a monetary contraction. We also show that the persistence of inflation rates differs sharply across industries. These empirical facts set the stage for our analysis of the sticky price mechanism in environments with flexibly priced durables. Section 3 presents the basic framework used in the analysis. Sections 4 and 5 present the two main puzzles in our paper: the robust comovement problems in the durable goods sectors and the potential for monetary neutrality even in models with significant nominal rigidity. Section 6 presents simulations of the model. Section 7 discusses possible resolutions to the comovement problem. Section 8 concludes.

\section{Durable Goods and Monetary Disturbances: Stylized Facts}

The fundamental theme of this paper is the tension between theory and data with respect to the behavior of durable goods markets following a monetary policy disturbance. In this section, we examine time series evidence on the prices and outputs of several categories of durables in the periods surrounding contractionary shifts in monetary policy. We confirm the conventional wisdom that the production of durables falls dramatically in response to a tightening of monetary policy. We then show that durable goods prices fall relative to the prices of nondurables following monetary contractions. A related finding is that inflation persistence differs significantly across 
sectors. Most notably, the prices of newly constructed houses display no inflation persistence at all.

We focus on the economy's behavior following a few clear-cut and dramatic changes in monetary policy. Specifically, we use Romer dates as indicators of pronounced monetary tightness. The advantages of this approach are that our attention is drawn to the most drastic changes in monetary policy and that it allows for the possibility that the important parts of monetary policy may be systematic. ${ }^{6}$ This approach does have shortcomings. As Shapiro (1992) demonstrates, these monetary contractions are not exogenous. Romer dates tend to occur when inflation is high and rising and unemployment is low. The "shocks" we identify are few in number and are not ranked by magnitude. Finally, there is reason to believe that the Romer dates come too late to catch the inception of monetary tightenings (Bernanke and Mihov, [1998]) - a problem that is mitigated, however, by the flexible approach taken below.

We document the behavior of several economic variables before and after these events. ${ }^{7}$ For any variable in levels we take the averages of $x_{t+j} / x_{t}$ given that $t$ is a Romer date for $j=-4, \ldots 16$. We compare this series with the averages of $x_{t+j} / x_{t}$ for all dates (again for $j=-4, \ldots 16$ ). The resulting series give us a window of observation on the economy during these episodes. We look before the date itself (i.e. before $j=0$ ) to see the events "leading up" to a Romer date. In addition, we suspect that Romer dates may lag the actual changes in policy. Bernanke and Mihov [1998] argue that Romer dates occur when their index describing the stance of monetary policy (the Bernanke-Mihov index) is at a trough, indicating that the actual change in monetary policy was made prior to the date.

Before proceeding to the results we should make a remark concerning the interpretation of the "trend" by which we mean the path of the ratios $x_{t+j} / x_{t}$ over the

\footnotetext{
${ }^{6} \mathrm{~A}$ common approach to the study of monetary policy effects is to examine impulse responses to "identified" monetary policy shocks from a structural VAR. This has the advantage that, in the best case, it identifies the truly exogenous component of monetary policy. However, by excluding the systematic component of monetary policy, structural VARs miss the lion's share of the variation. The innovations in the federal funds rate identified by a VAR may not be monetary policy shocks at all, but rather the result of misspecification, omitted variables, or uninterpretable noise. Finally, we suspect important nonlinearities that render the results of occasional large interventions particularly potent. For analysis using the VAR approach, see Erceg and Levin [2003].

${ }^{7}$ This approach goes back to Burns and Mitchell and was used recently in Doyle and Faust [2001].
} 
horizon $j=-4, \ldots 16$, averaged over all dates. Statistically, this average path is the best predictor of the relative size of the variable $x, j$ periods after (or before) an arbitrary date $t$. Economically, this corresponds to the trend growth path. For some variables following a Romer date, there is a tendency to fall below "trend" and not recover. This is due to the fact that the timing of the Romer dates is endogenous. Typically Romer dates occur when the economy is "above trend". So, when a variable falls relative to its trend growth path, some of the response should be interpreted as simple mean reversion.

Figures 1.a, 1.b, and 1.c show the average behavior of several economic variables in the quarters following a Romer date. The figures include bands to indicate one standard deviation around the point estimates. One thing to notice immediately is that the response of these variables is much more dramatic than responses following "shocks" in a VAR. The main reason for this difference is that the "events" we are considering (i.e. Romer dates) do not correspond to small "shocks" to a stable monetary policy rule but rather represent a fundamental change in monetary policy. In a typical VAR system, a 1\% shock to the federal funds rate reverts to a "normal" level quickly and induces only mild responses in GDP and the components of production. Following a Romer date, the federal funds rate continues to increase by roughly 4 points (400 basis points). In fact, the rise in the funds rate is more than this when we take into account the fact that interest rates were rising before the Romer event (see Figure 1.c).

In Figure 1.a, we see that following a Romer date, durable goods sectors contract very sharply while nondurable goods (and overall GDP) do not. Relative to levels in the reference period (the Romer date), housing starts fall by approximately $33 \%$. The trough occurs seven quarters after the Romer date. Starts remain more than $20 \%$ below the reference level for nine quarters (from $t+4$ until $t+12$ ). Real residential investment also falls substantially. After nine quarters, residential investment is $22 \%$ lower than it was in the reference date. Real automobile sales fall by $25 \%$ after eight quarters. They remain more than $10 \%$ below the level in the base date for eight quarters (from $t+4$ until $t+11$ ). ${ }^{8}$ Finally, real durables purchases fall by $12.5 \%$ relative to the reference date. The trough occurs eight quarters after the event. In contrast, nondurables and GDP as a whole react much less dramatically. Real purchases of nondurables rise above trend immediately

\footnotetext{
${ }^{8}$ The point estimate is below $10 \%$ again 13 quarters following the shock (but not in quarter 12).
} 
following the event (although insignificantly) and fall below "trend" after seven quarters. Real GDP does not fall relative to its level in the reference date. Relative to "trend" it falls by $6 \%{ }^{9}$

In addition to the large effects on durables spending, monetary policy also has significant affects on the relative prices of durables and nondurables. The top four panels of Figure 1.b show the average responses of four relative prices following a Romer date. The price of new houses relative to the CPI for nondurables falls by $12 \%$ in comparison to the reference date. ${ }^{10}$ The trough occurs nine quarters after the Romer date. The relative price of cars (measured as the CPI for new autos relative to the CPI for nondurables) falls by more than $6 \%$ relative to the base date after five to seven quarters. Note that the relative price of cars has been falling over time (as shown by the dashed line) so this drop is not as significant. Relative to "trend" the maximum drop is only $5 \%$. The price of durables relative to nondurables (both measured by their respective CPIs) falls by $4.8 \%$ relative to the reference date (again the trend for the relative price of durables is negative; relative to the trend growth rate, the drop is only $3.7 \%) .{ }^{11}$

The bottom two panels focus on the housing market. The left hand side panel depicts the evolution of the median house price after the reference date. Although the median house price continues to rise, its rate of inflation drops immediately after the base date. The right hand side panel shows the average response of lumber prices around a Romer date. Because Romer dates occur during periods of high and rising inflation, prices of almost all goods rise both before and after the monetary contraction begins. Lumber and plywood are notable exceptions. Lumber prices literally fall within one quarter of the Romer date. After seven quarters they are $6 \%$ below their initial level. Since lumber prices contribute to the production cost of houses, this indicates downward pressure on the marginal cost of production in construction.

Figure 1.c shows the unemployment rate, the federal funds rate, the rate of inflation and the total level of employment. All of these variables respond according to conventional wisdom. The unemployment rate rises by almost 3 percentage points

\footnotetext{
${ }^{9}$ Aggregate employment follows a similar pattern (Figure 1.c).

${ }^{10}$ This number is for the median house price. The number for the average house price is similar.

${ }^{11}$ While impulse responses to monetary shocks in identified VARs show strong responses of quantities of durable production and housing production to monetary shocks, they do not exhibit the pronounced movement in relative prices. See Erceg and Levin [2003] for instance.
} 
following a Romer date. Total employment falls only slightly though it has a much slower rate of growth than average. According to our data, the average increase in the federal funds rate is almost seven percentage points from four periods before the Romer date to seven quarters afterwards. Most of this increase is due to the very sharp increases in interest rates in the early 1980 s.

Following a Romer date, inflation continues to rise for six quarters. Recent literature emphasizes that the inflation rate, not just the price level, is sticky (see e.g. Mankiw and Reis [2001]). Moreover, even sticky price models that allow inflation to jump imply serially correlated inflation because price adjustment each period is partial. Table 1 reports autocorrelations for several price series. For the overall CPI, for durables and to a somewhat lesser extent for nondurables, inflation is highly persistent. ${ }^{12}$ By this measure, the CPIs for both nondurables and durables display stickiness. Automobiles have notably less inflation inertia. However, the most noteworthy feature of this data is that housing inflation has no persistence at all. Its first autocorrelation is negative which implies that, unlike other prices, housing prices tend to overshoot. Incomplete (partial) nominal adjustment implies that prices undershoot. This suggests that house prices may be quite flexible.

To summarize, the production of durables responds significantly to changes in monetary policy while the production of nondurables does not. Moreover, the relative price of durable goods to nondurable goods appears to fall after a monetary contraction. In particular, housing starts fall by more than $30 \%$ and the price of new houses relative to nondurables falls by roughly $10 \%$. In addition, while there is strong evidence of inflation persistence in many price series, there is no inflation persistence in housing prices. Housing prices appear to overshoot rather than partially adjust to shocks.

\section{Framework}

In this section we consider a dynamic economy with many industries or sectors. Some industries produce durable goods while the others produce nondurables. In addition, some of the goods have sticky prices while others have flexible prices. We

\footnotetext{
${ }^{12}$ Inflation of durable goods as a whole is more persistent than the inflation of nondurables. Automobiles have lower inflation persistence than either nondurable goods or durable goods as a whole.
} 
assume that there is at least one industry that produces durables and has flexible prices. In the durables sectors, we focus on durable consumption goods instead of productive capital in order to emphasize that it is durability that is the key issue and not what the good is used for. ${ }^{13}$

For this simple model we treat productive capital as a predetermined fixed factor but we allow labor to flow freely across industries. Later we will relax both of these assumptions. One consequence of labor mobility is that the nominal wage rate $W_{t}$ will be the same across industries. Because our focus is on the role of sticky prices in generating business cycles, we assume that firms have constant desired markups over their marginal costs of production ${ }^{14}$. Any deviations from these desired markups must come from nominal rigidities; the sticky prices in the final goods markets do all of the work in our model.

\subsection{Household behavior}

Consumers get utility from both nondurable consumption goods and durable consumption goods. We denote a typical durable good as $d_{j t}$ and a typical nondurable good as $c_{j t}$. Total utility is time separable and additively separable in labor.

$$
U=E\left(\sum_{t=0}^{\infty} \beta^{t}\left[u\left(c_{1 t}, c_{2 t} \ldots, c_{j t}, \ldots d_{1 t}, d_{2 t}, \ldots d_{j t} \ldots\right)-v\left(N_{t}\right)\right]\right)
$$

$N_{t}$ is labor supplied at date $t$. The additive separability of labor is to some extent important for our results. We will return to this point later.

Let $x_{j t}$ denote the net purchases of type $j$ goods at time $t$. The household's nominal budget constraint is then simply:

$$
\sum_{j} P_{j t} x_{j t} \leq W_{t} N_{t}+\Pi_{t}+T_{t}+\left(1+i_{t-1}\right) S_{t-1}-S_{t},
$$

where $\Pi_{t}$ are profits returned to the consumer through dividends, $T_{t}$ are nominal transfers net of taxes, $S_{t}$ is nominal savings and $i_{t}$ is the nominal interest rate. Note that for nondurable goods $c_{j t}=x_{j t}$ while for durable goods we have:

\footnotetext{
${ }^{13}$ We discuss productive capital briefly in sections 5 and section 7.

${ }^{14}$ In the model we spell out for the simulations, this will be justified with a C.E.S. (Dixit-Stiglitz) preference structure. In general, firms will desire markups that fluctuate with changes in demand. See Bils [1989] for a discussion of endogenous markups.
} 


$$
d_{j t}=x_{j t}+d_{j t-1}\left(1-\delta_{j}\right) .
$$

We allow for different rates of physical depreciation for different durable goods.

\section{Labor Supply and the Demand for Goods and Services}

Taking prices as given, the consumer chooses $x_{j t}$ and $N_{t}$ to maximize utility. Let $\lambda_{t}$ be the marginal utility of an additional dollar of income at time $t$ and let $\gamma_{j t}$ be the shadow value - the contribution to lifetime utility of an additional unit - of $\operatorname{good} j$. Good $j$ can be either a durable good or a nondurable good. If $j$ is a nondurable, then $\gamma_{j}=M U\left(c_{j}\right)$. If instead $j$ is a durable good, its shadow value is:

$$
\gamma_{j t}=M U\left(d_{j t}\right)+\beta\left(1-\delta_{j}\right) M U\left(d_{j t+1}\right)+\beta^{2}\left(1-\delta_{j}\right)^{2} M U\left(d_{j t+2}\right)+\ldots
$$

i.e. $\gamma_{j t}$ is the present value of future marginal service flows of the durable, discounted by the subjective rate of time preference and the depreciation rate. The latter can be thought of as an index of durability.

Purchasing an additional amount of any good results in the following change in utility:

$$
\gamma_{j t}-\lambda_{t} P_{j t} .
$$

If the consumer is maximizing utility, this must be zero. The first order condition for the supply of labor $\left(N_{t}\right)$ satisfies $v^{\prime}\left(N_{t}\right)=\lambda_{t} W_{t}$. Jointly, these first order conditions represent the demand for goods and services and the supply of labor.

Combining (3.2) with the first order condition for labor supply gives a set of conditions (one for each good) that relate labor supply to the demand for goods and services:

$$
v^{\prime}\left(N_{t}\right)=\left(W_{t} / P_{j t}\right) \gamma_{j t} .
$$

Equation (3.3) states that the utility cost of an additional unit of labor must be exactly balanced by the benefit of spending the $W_{t}$ extra dollars on any of the goods in the economy. Equations (3.3) and (3.1) turn out to be the key equations in the model. 


\section{Money Demand}

For simplicity we assume that money demand is proportional to nominal purchases:

$$
M_{t}=\sum_{j} P_{j t} x_{j t}
$$

Here, $M$ is the nominal money supply (the "velocity" of money is 1 ). Money is injected into the economy through lump sum transfers $T_{t}$ to the agents ( $T_{t}$ can be negative). Of course, money demand might also be related to the nominal interest rate (an "LM curve") or other macroeconomic variables, but this is inessential. The important feature of money demand is that when the money supply increases, firms have incentives to raise their prices.

\subsection{Firm Behavior}

Firms convert labor input into outputs according to their production functions.

$$
x_{j t}=F_{j}\left(n_{j t}\right)
$$

We allow each firm to have a different production function. We assume that each $F_{j}$ satisfies $F_{j}{ }^{\prime}>0$ and $F_{j}{ }^{\prime \prime} \leq 0$ so that all production has non-increasing returns to scale in labor. The nominal marginal cost of production is the cost of hiring an additional unit of a productive input times the number of inputs required to produce an additional unit of output. In this simple case, labor is the input to production; we write $M C_{j t}=W_{t}$ $((\partial n) /(\partial q))=W_{t}\left[M P_{j t}{ }^{N}\right]^{-1}$ where $M P_{j t}{ }^{N}$ is the marginal product of labor.

We assume that some firms are able to change prices every period, while some firms must keep prices fixed for at least one period after a monetary shock. ${ }^{15}$ Firms with fully flexible prices simply maintain their constant desired markups - for these firms $\mu_{j t}$ $=\mu$ at all times. In a period of monetary expansion, firms that cannot change their prices will have actual (or ex post) markups that fall below the planned or ex ante level.

\section{The Comovement Problem}

\footnotetext{
${ }^{15}$ In the simulations, we use a Calvo specification to generate price rigidity. We do not need to take a position on the exact form of price stickiness at this point.
} 
Consider an expansion in the money supply. Instead of raising their prices, firms with sticky prices increase production, as in standard one-sector sticky price models. What about the flexible price firms? In this section we demonstrate that the behavior of a flexible price sector that produces durable goods differs radically from what the standard model might lead us to expect.

Recall equation (3.1) for the shadow value of a durable good:

$$
\gamma_{j t}=M U\left(d_{j t}\right)+\beta\left(1-\delta_{j}\right) M U\left(d_{j t+1}\right)+\beta^{2}\left(1-\delta_{j}\right)^{2} M U\left(d_{j t+2}\right)+\ldots
$$

The steady state stock/flow ratio is $1 / \delta$ in a static model and $1 /(\delta+$ growth rate $)$ in a growing economy. For a highly durable good, this ratio is by definition high. The relatively small fluctuations around the steady state that (in the standard model) constitute the business cycle leave the stock of such a highly durable good nearly constant at cyclical frequencies. Presuming for the moment that the marginal utilities above depend only on the stock of the durable (an assumption that will be relaxed later in this section), we conclude that $\gamma_{j t}$ will display minimal cyclical movement.

Consider an industry that produces highly durable goods and sells them at a perfectly flexible price. The acyclicality of the stock - and hence the shadow price - of durables leads us to drop the time subscript and treat $\gamma_{j t}$ as roughly constant at some $\gamma_{j}$. Thus durability implies $v^{\prime}\left(N_{t}\right) \approx\left(W_{t} / P_{j t}\right) \gamma_{j}$. The fact that the sector has flexible prices means that the price of this good is a constant markup over its marginal cost: $P_{j t}=\mu_{j}$ $\left(W_{t} / M P_{j t}{ }^{N}\right)$. Combining these expressions (in essence, equating labor supply and labor demand) implies that:

$$
v^{\prime}\left(N_{t}\right) \cong \frac{\gamma_{j}}{\mu_{j}} M P_{j t}^{N}
$$

If aggregate employment rises in response to expansionary monetary policy, then $v^{\prime}\left(N_{t}\right)$ rises, reflecting the fact that workers are being drawn up their labor supply curves. To maintain equality, the right hand side of equation (4.1) must also rise. With $\gamma_{j}$ and $\mu_{j}$ time-invariant, the marginal product of labor must rise and employment in this durables sector falls. This is a very general result. Employment and output of a long- 
lived durable industry with flexible prices must move in the opposite direction from aggregate employment and output.

\section{Sticky Prices and the Neutrality of Money}

If all durables have flexible prices, production has constant returns to scale, and factors can move freely across sectors, then money is neutral with respect to aggregate output and employment regardless of the degree of nominal rigidity in the nondurables sectors. The percentage change in the aggregate price index (the model's version of the GDP deflator) will be equal to the percentage change in the money supply. This will be approximately true regardless of how much price rigidity there is in the nondurable sectors and regardless of the ratio of nondurables to durables. Even if the nondurables sectors have very sticky prices and even if there are many more nondurables than durables in GDP, money will be approximately neutral.

\section{Labor Inputs Only}

The simplest way to see the neutrality result is to consider a case in which production requires only labor with $x_{j t}=A_{j} N_{j t}$ in every sector (so that production has constant returns to scale). The labor market clearing condition for a durable goods sector (d) implies that

$$
v^{\prime}\left(N_{t}\right)=\frac{\gamma}{\mu} M P_{d t}^{N}
$$

but because $M P_{d t}^{N}=A_{d}$ we have one equation in the one aggregate variable $N_{t}$. As before, the other terms are constants because of flexible prices and durability. The level of employment that solves this equation following a monetary shock is the same as the level of employment in the steady state. As a result, aggregate labor will not vary over the cycle and money will be neutral.

\section{$\underline{\text { Mobile Capital }}$}

The neutrality result demonstrated in the previous subsection requires that durable goods production is linear in labor. If instead capital is mobile across sectors, then it is no longer necessary to make this assumption. A constant marginal product of labor can arise 
endogenously in equilibrium. Specifically, assume that production in each sector has the constant returns to scale production function:

$$
x_{j t}=F\left(k_{j t}, n_{j t}\right)
$$

(we assume that $F$ is symmetric across sectors). Because factors can flow freely across industries, nominal wages and rental prices will be equal in each sector. In addition, the firms will always choose a combination of inputs to minimize their costs (given their output decision). Since the production function is homogeneous of degree one, cost minimization implies that the capital-to-labor ratios will equalize across all sectors regardless of which ones have sticky prices and which have flexible prices. Industries that increase production do so by hiring capital and labor in the same proportions as other industries. Summing over all sectors gives us:

$$
\frac{k_{i t}}{n_{i t}}=\frac{k_{j t}}{n_{j t}}=\frac{K_{t}}{N_{t}} .
$$

The marginal product of labor in any sector depends only on the capital-to-labor ratio:

$$
M P_{j t}^{N} \equiv \frac{\partial F\left(k_{j t}, n_{j t}\right)}{\partial n_{j t}}=F_{N}\left(1, \frac{n_{j t}}{k_{j t}}\right)=\varphi\left(\frac{k_{j t}}{n_{j t}}\right)=\varphi\left(\frac{K_{t}}{N_{t}}\right) .
$$

Finally, returning to the labor market clearing condition in the durable goods sector, we have:

$$
v^{\prime}\left(N_{t}\right)=\frac{\gamma}{\mu} M P_{j t}^{N}=\frac{\gamma}{\mu} \varphi\left(\frac{K_{t}}{N_{t}}\right) .
$$

Like all of the other durable goods, the aggregate capital stock does not move much over the cycle. Because $K_{t}$ is a "slow moving" component of the model we can safely treat the aggregate capital stock as approximately fixed over business cycle horizons. This gives us, again, one equation in aggregate employment $\left(N_{t}\right)$, so that, to a first approximation, employment is constant over the cycle and money is neutral.

\section{$\underline{\text { Discussion }}$}

What is the underlying mechanism generating the comovement and neutrality results? Following a monetary expansion, sticky price firms continue to meet demand at the fixed price. In terms of utility, the marginal cost of an additional unit of good $j$ is $v^{\prime}\left(N_{t}\right) / M P_{j t}^{N}$. The incipient increase in output in the sticky price sector increases the 
demand for labor which, in turn raises $v^{\prime}\left(N_{t}\right)$ and raises marginal cost. In a more general model, as the economy expands, pressure on all input markets (labor markets, markets for fuel and raw materials, etc.) rises.

In the face of rising marginal costs, flexible price firms maintain their markups by raising prices. As prices adjust, employment returns to its steady state level. As a result, the increase in real marginal costs and real durables prices is inherently temporary. Is there a sufficient shift in demand for the flexibly priced product to more than offset the contractionary effect of the price increase? For a sufficiently long-lived durable good, the answer is no. The demand schedule for such a good cannot shift very much in the short run because the shadow value of a long-lived durable is largely invariant to cyclical deviations from the steady state. ${ }^{16}$ The stock of the durable moves slowly, and the contribution to lifetime utility of an additional unit of the durable is the sum of flow utilities extending into the distant future (see equation (3.1)). Because the demand for durables is driven by long run considerations, while the rise in the price of durables is temporary, consumers intertemporally substitute and postpone durables purchases. Thus the adverse price movement is the dominant effect of the monetary expansion on the flexible price durables sector. The neutrality result is an extreme case of the comovement problem. In this limiting case, intertemporal substitution for durables purchases is essentially infinite, and the durables sector is in equilibrium only when the price is precisely equal to its steady state value.

\section{Simulations}

In this section we use a computable general equilibrium model to demonstrate our results. The model has two sectors: a durable goods sector and a nondurable goods sector. Our specification allows the durable to function as either productive capital or as a final consumption good. The utility function takes the following form:

\footnotetext{
${ }^{16}$ This approximation works because of an implicit assumption that price adjustment is not extremely slow. If price adjustment were sufficiently slow, then the distinction between the long run (which determines the shadow value of a durable) and the short run would become blurred.
} 


$$
\sum_{t=0}^{\infty} \beta^{t}\left\{\frac{1}{1-\frac{1}{\sigma}}\left[\left(\psi_{c} C_{t}^{1-\frac{1}{\rho}}+\psi_{d} D_{t}^{1-\frac{1}{\rho}}\right)^{\frac{\rho}{1-\rho}}\right]^{1-\frac{1}{\sigma}}-\phi \frac{N_{t}^{1+\frac{1}{\eta}}}{1+\frac{1}{\eta}}\right\}
$$

The CES aggregator has the (standard) properties that as the elasticity of substitution $\rho$ $\rightarrow \infty, C$ and $D$ become perfect substitutes, as $\rho \rightarrow 1$ the Utility function is the generalized Cobb-Douglas function $C_{t}^{\psi_{c}} D_{t}^{\psi_{d}}$, and as $\rho \rightarrow 0$, the utility function becomes Leontief so that $C_{t}$ and $D_{t}$ are perfect complements. $\sigma$ is the intertemporal elasticity of substitution, and $\eta$ is the labor supply elasticity ( $\phi$ is simply a scaling parameter). The stock of durable goods obeys:

$$
D_{t}=D_{t-1}(1-\delta)+X_{t}
$$

where $X_{t}$ is the production of new durable goods. Using the budget constraint, the consumer's optimal choices are governed by an Euler equation:

$$
M U\left(C_{t}\right) \frac{P_{t}^{x}}{P_{t}^{c}}=M U\left(D_{t}\right)+\beta(1-\delta) E_{t}\left[M U\left(C_{t+1}\right) \frac{P_{t+1}^{x}}{P_{t+1}^{c}}\right]
$$

and a labor supply equation:

$$
v^{\prime}\left(N_{t}\right)=\frac{W_{t}}{P_{t}^{c}} M U\left(C_{t}\right)
$$

Our specific functional forms imply that these equations are:

$$
\begin{gathered}
U_{t}^{\frac{1}{\rho}-\frac{1}{\sigma}} C_{t}^{-\frac{1}{\rho}} \frac{P_{t}^{x}}{P_{t}^{c}}=U_{t}^{\frac{1}{\rho}-\frac{1}{\sigma}} \frac{\psi_{d}}{\psi_{c}} D_{t}^{-\frac{1}{\rho}}+\beta(1-\delta) E_{t}\left[U_{t+1}^{\frac{1}{\rho}-\frac{1}{\sigma}} C_{t+1}^{-\frac{1}{\rho}} \frac{P_{t+1}^{x}}{P_{t+1}^{c}}\right] \\
\phi N_{t}^{\frac{1}{\eta}}=\psi_{c} \frac{W_{t}}{P_{t}^{c}} U_{t}^{\frac{1}{\rho}-\frac{1}{\sigma}} C_{t}^{-\frac{1}{\rho}}
\end{gathered}
$$

where $U_{t}$ is defined as $U_{t}=\left(\psi_{c} C_{t}^{1-\frac{1}{\rho}}+\psi_{d} D_{t}^{1-\frac{1}{\rho}}\right)^{\frac{\rho}{1-\rho}}$. We maintain our simple money demand structure from section 3:

$$
M_{t}=P_{t}^{c} C_{t}+P_{t}^{x} X_{t}
$$

We make assumptions that are standard in the literature on nominal rigidity. Specifically, we assume that final goods in each sector are produced from a mix of intermediate goods according to the Dixit-Stiglitz aggregators: 


$$
\begin{aligned}
& X_{t}=\left[\int_{0}^{1} x_{t}(s)^{\frac{\varepsilon-1}{\varepsilon}} d s\right]^{\frac{\varepsilon}{\varepsilon-1}} \\
& C_{t}=\left[\int_{0}^{1} c_{t}(s)^{\frac{\varepsilon-1}{\varepsilon}} d s\right]^{\frac{\varepsilon}{\varepsilon-1}}
\end{aligned}
$$

We assume that $\varepsilon>1$. The final goods producers are competitive while each intermediate goods producer enjoys a local monopoly on its product. Free entry into the production of final goods implies that:

$$
\begin{aligned}
& P_{t}^{x}=\left[\int_{0}^{1} p_{t}^{x}(s)^{1-\varepsilon} d s\right]^{\frac{1}{1-\varepsilon}} \\
& P_{t}^{c}=\left[\int_{0}^{1} p_{t}^{c}(s)^{1-\varepsilon} d s\right]^{\frac{1}{1-\varepsilon}}
\end{aligned}
$$

while the demand for any one intermediate good $(s)$ satisfies:

$$
\begin{aligned}
& x_{t}(s)=X_{t}\left(\frac{p_{t}^{x}(s)}{P_{t}^{x}}\right)^{-\varepsilon} \\
& c_{t}(s)=C_{t}\left(\frac{p_{t}^{c}(s)}{P_{t}^{c}}\right)^{-\varepsilon}
\end{aligned}
$$

so that $\varepsilon$ is the price elasticity of demand. Because the elasticity of demand is constant in this setting, firms with completely flexible prices will choose markups over nominal marginal costs that are constant (this markup will be: $\mu=\frac{\varepsilon}{\varepsilon-1}>1$ ).

We assume that the production of intermediate goods in each industry is simply linear in employment ${ }^{17}$ so that:

$$
\begin{aligned}
& c_{t}(s)=A n_{t}^{c}(s) \\
& x_{t}(s)=A n_{t}^{x}(s)
\end{aligned}
$$

Because we allow for frictionless labor mobility across sectors, nominal marginal costs in either industry are simply $M C_{t}=W_{t} / A$, where $W_{t}$ is the nominal wage.

We motivate price rigidity with a Calvo price setting mechanism. Specifically, let

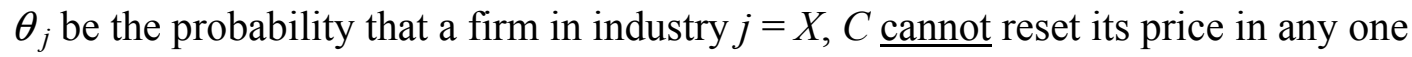

\footnotetext{
${ }^{17}$ This specification is somewhat unorthodox. We use it because it allows us to have constant returns to scale (to illustrate the neutrality result), without having to introduce capital as an additional durable good.
} 
period. Thus, in each period, $1-\theta_{j}$ firms reset their prices while $\theta_{j}$ firms have prices that are stuck at their levels from the previous period. When a firm gets to set its price, it chooses a price that makes its expected average markup over the foreseeable future equal to its desired markup (see the appendix for details). As a result, the optimal reset price is a weighted average of current marginal costs and future marginal costs. Let $\tilde{z}$ denote the percentage deviation of a variable $z$ from its steady state value. Then to a first order approximation, the optimal reset prices in each sector satisfy:

$$
\begin{aligned}
\tilde{P}_{t}^{c, *} & =\left(1-\theta_{c} \beta\right) \tilde{W}_{t}+\theta_{c} \beta E_{t}\left[\tilde{P}_{t+1}^{c, *}\right] \\
\tilde{P}_{t}^{x, *} & =\left(1-\theta_{x} \beta\right) \tilde{W}_{t}+\theta_{x} \beta E_{t}\left[\tilde{P}_{t+1}^{x, *}\right] .
\end{aligned}
$$

Note that if there were no price rigidity, $\theta=0$ and prices would be proportional to marginal costs (the markup would be constant). Using (6.10) and (6.11), the final goods prices are weighted averages of the reset price and previous prices.

$$
\begin{aligned}
& \tilde{P}_{t}^{c}=\theta_{c} \tilde{P}_{t-1}^{c}+\left(1-\theta_{c}\right) \tilde{P}_{t}^{c, *} \\
& \tilde{P}_{t}^{x}=\theta_{x} \tilde{P}_{t-1}^{x}+\left(1-\theta_{x}\right) \tilde{P}_{t}^{x, *}
\end{aligned}
$$

Note that because the Calvo mechanism randomly draws out $\mathrm{g}$ firms and allows them to change their prices, the aggregate production of durable and nondurable goods will satisfy:

$$
\begin{aligned}
& C_{t}=A N_{t}^{c} \\
& X_{t}=A N_{t}^{x}
\end{aligned}
$$

where $N_{t}^{j}=\int n_{t}^{j}(s) d s$ for $j=X, C$. Equilibrium in the labor market requires:

$$
N_{t}=N_{t}^{x}+N_{t}^{c}
$$

Finally, we need to specify a process for the money supply. For simplicity we assume that the money supply follows a random walk (so that shocks to $\mathrm{M}$ are permanent):

$$
M_{t}=M_{t-1}+\xi_{t},
$$

where $\xi_{t}$ is a mean zero i.i.d. disturbance.

\section{Parameter Values:}


We choose parameter values that are typical for standard business cycle models. We set the parameters $\sigma$ and $\eta$ (the intertemporal elasticity of substitution and the Frisch labor supply elasticity) to 1 . We set the annual discount factor $(\beta)$ to .98 so that the real interest rate is $2 \%$ per year. $\phi$ is normalized so that $N$ is 1 in the steady state. We assume that $\rho=1$ so that the within-period utility function has the generalized Cobb-Douglas form: $C_{t}^{\psi_{c}} D_{t}^{\psi_{d}} . \varepsilon$ is set so that the desired markup is $10 \%$. We assume that the depreciation rate for the durable good is $10 \%$ annually. ${ }^{18}$ Finally, $\psi_{c}$ and $\psi_{d}$ are chosen so that the steady state ratio of consumption to total output is .75. Table 1 summarizes these parameter choices:

\begin{tabular}{l|c}
\hline Parameter & Value \\
\hline$\beta$ (discount rate) & .98 \\
$\rho$ (elasticity of sub. betw. durables and nondurables) & 1 \\
$\eta$ (labor supply elasticity) & 1 \\
$\sigma$ (intertemporal elasticity of substitution) & 1 \\
$\delta$ (depreciation rate) & .1 \\
$\mathcal{E}$ (elasticity of demand for intermediate goods) & 11 \\
$C / Y$ (fraction of nondurables in GDP) & .75 \\
\hline
\end{tabular}

Table 2

The model is solved by log-linear approximation in the neighborhood of the nonstochastic steady state using the Anderson-Moore (AIM) algorithm.

\footnotetext{
${ }^{18}$ Buildings have depreciation rates that are closer to $5 \%$, vehicles and transportation equipment have depreciation rates that are closer to $15 \%$. We use $10 \%$ because it is a standard value in the business cycle literature (the depreciation rate for equipment and machinery is roughly $8-10 \%$ ). See Hulten and Wykof (1979) and (1981).
} 
To give the reader a sense of how a "normal" sticky price model responds to a monetary shock, we begin with a standard New Keynesian model in which both the durable sector and the nondurable sector have equally sticky prices.

\section{Symmetric Price Rigidity}

In the benchmark model, prices are equally sticky throughout the economy. We assume that the half-life of exogenous price rigidity is six months (i.e. for any firm, there is a $50 \%$ chance that it will be able to reset its price within half a year). For models with staggered price setting, this corresponds to one year of fixed prices. A half-life of six months requires a continuous time annual Calvo parameter of $2 \ln (2)=1.3863$, meaning that on average firms get to reset prices 1.4 times per year. ${ }^{19}$ This is a considerable amount of exogenous price rigidity. Bils and Klenow [2002] find that prices of most consumer goods are reset, on average, once every four months, which suggests a Calvo parameter closer to 3 .

We assume that $75 \%$ of total GDP consists of nondurable production. The aggregate labor supply elasticity and the intertemporal elasticity of substitution are both set to 1 . The depreciation rate for the durable good is $10 \%$ annually.

Figure 2.a shows the impulse response of our benchmark model to a permanent, unanticipated $1 \%$ increase in the money supply. $C$ is aggregate production (and consumption) of the nondurable good and $X$ is the production of the durable; 100 periods corresponds to one year. In the figure, as prices adjust, employment and output rise. In the first quarter following the shock (the first 25 periods in the figure), total output rises by $0.83 \% .{ }^{20}$ Of course if prices were more rigid the model would generate greater responses. For instance, if firms could change prices only once every two years (on average) then output would rise by $0.93 \%$ in the first quarter.

Production of the durable good rises sharply following the shock $(3.8 \%$ in the first quarter) while production of nondurable consumption goods rises by much less. Because the stock of durables does not change much over the cycle, production of the durable

\footnotetext{
${ }^{19}$ The probability of a price being stuck for an entire year is $.25=\exp (-1.3863)$.

${ }^{20}$ The plot makes it look like output rises by $1 \%$ because it is plotting the first $100^{\text {th }}$ of a year rather than the first quarter. Note that because output is linear in employment, the employment response is also $0.83 \%$. For the standard New Keynesian model with productive capital, the same experiment implies that employment and output increase by roughly $0.79 \%$ and $0.52 \%$, respectively.
} 
good can be varied considerably without changing the shadow value of the durable significantly. On the other hand, nondurable consumption cannot change without significant changes in its marginal utility. Said another way, purchases of the nondurable good obey the permanent income hypothesis (PIH) while purchases of the durable do not. $^{2122}$

In fact, the reader may be surprised at how small the change in nondurable production is when both durable and nondurable prices are sticky. The reason for this is fairly simple. Because prices are equally sticky, the production functions are identical, and there is a common labor market for the two sectors, prices will be identical in the durable and nondurable sectors. Labor supply satisfies equation (1.3) for each sector. For the durable goods sector, this says that $v^{\prime}\left(N_{t}\right)=\left(W_{t} / P_{t}\right) \gamma_{d t}$ while for the nondurable consumption sector we have $v^{\prime}\left(N_{t}\right)=\left(W_{t} / P_{t}\right) u^{\prime}\left(C_{t}\right)$. Thus, $u^{\prime}\left(C_{t}\right)=\gamma_{d t}$. If the stock/flow distinction for the durable is strong, then $\gamma_{d t} \approx \bar{\gamma}_{d}$ which implies that $u^{\prime}\left(C_{t}\right)$ and $C_{t}$ are approximately constant. Another interesting consequence of the model is that if nondurable consumption rises in response to a monetary expansion then the relative price of durables $\left(P^{x} / P^{c}\right)$ must be high. If prices are equally sticky, this ratio is constant and as a result consumption is constant.

This is a sort of "neutrality" result for nondurable goods. With additively separable utility, the presence of durables means that no matter how sticky the nondurable prices are, their production won't change. This contrasts with the results in a model without durables, shown for purposes of comparison in Figure 2.b. Sticky price theories of the business cycle are entirely consistent with very sticky Coca Cola prices and the observation that Coca Cola does not respond to monetary policy. As long as durable goods have sticky prices, the fact that there are nondurables with sticky prices that don't respond to monetary policy isn't a concern to business cycle researchers. The converse of this is not true. Sticky price theories imply that durable goods with flexible prices should comove negatively with employment. Our next simulation presents this case.

\footnotetext{
${ }^{21}$ See Mankiw [1982].

${ }^{22}$ Note that nominal interest rates rise after the monetary expansion. Most of this is due to anticipated inflation rather than changes in the real rate of return. In models with capital, increases in employment cause the marginal product of capital to rise. The link between the marginal product of capital and the real interest rate implies that in sticky price models with capital, real interest rates also have a strong tendency to rise (see Tobin [1955] and also Sargent [1987] chapter 3).
} 


\section{$\underline{\text { Flexible Durables Prices and Sticky Nondurables Prices }}$}

Figure 3 shows the response of the model when only the nondurable good has sticky prices. Again, we consider a permanent increase in the money supply of $1 \%$. This figure illustrates the two central results of our paper. First, even though the production of nondurables accounts for $75 \%$ of GDP, output barely changes after the money shock. GDP - and consequently aggregate employment - rises by only $0.1 \%$ in the quarter following the shock. Even though most prices in this economy are sticky, money is approximately neutral with respect to aggregate employment and aggregate output. The source of this neutrality is, of course, the comovement problem. Consumption rises by $2.45 \%$ and production of durables falls by roughly $7 \%$ in the first quarter.

Notice that both the nominal interest rate and the real interest rate fall after the monetary expansion. Thus, even though durables are perceived as "interest sensitive" components of aggregate expenditure, the low interest rate does not increase demand for these goods enough to counteract the effect of the increased cost of producing durables.

\section{$\underline{\text { Sticky Durables Prices and Flexible Nondurables Prices }}$}

To show that this result is not simply a consequence of having one sector with sticky prices and another sector with flexible prices we now consider the opposite case -sticky durables prices and flexible nondurables prices. Recall that the durables industry is the smaller industry so only $25 \%$ of GDP has sticky prices in this case. Figure 4 shows impulse responses for the same $1 \%$ increase in the money supply.

Even though durables (the sticky price goods) only make up $25 \%$ of GDP, output rises by $0.45 \%$. The output response is almost five times greater than in the case with sticky nondurables prices. In fact, the increase in output is more than half of the increase when all prices were sticky. In addition, the comovement problem that was so pronounced in the first case is greatly alleviated. Although consumption falls by $0.45 \%$ in the first quarter, durable goods production rises by 3.18 percent. This is much closer to the behavior we see in the data. ${ }^{23}$

\footnotetext{
${ }^{23}$ Recall that following a Romer date, nondurable consumption rises slightly.
} 
This "reverse" experiment shows that aggregate output and employment respond to money shocks only if the durable goods sector has sticky prices. Very flexible durable goods prices result in approximate monetary neutrality even if the nondurables prices are very sluggish. However, the opposite is not true. Money is not neutral if nondurables prices are flexible but durables prices are sticky.

\section{$\underline{\text { Sensitivity }}$}

Figure 5 plots the first quarter response of output to a shock as we vary the share of the sticky price sector. The solid line represents the model when durables prices are sticky. The dashed line is for the model with sticky prices for the nondurables sector. ${ }^{24}$ As the figure shows, the responses of the economy depend importantly on which sector has sticky prices. Not surprisingly, as the share of sticky price sectors falls, the output response gets smaller. When the sticky price goods are nondurables, however, the output response falls drastically as we reduce the fraction of sticky price sectors in GDP. Even when $80 \%$ of GDP has sticky prices, the output response is less that $20 \%$ of the response when all prices are sticky. In contrast, when the durables have sticky prices the fall in the output response is much less severe. Even when only $20 \%$ of GDP has sticky prices, the response of output is still half of what it is when all prices are sticky. We get greater increases in output and employment when 10\% of GDP are durables with sticky prices than when $90 \%$ of GDP are nondurables with sticky prices. The message of this experiment is clear: in an economy with durable goods, sticky prices are important only if some durable goods have sticky prices.

How many durable goods sectors need to have sticky prices? To address this question we run the same experiments on a four-sector variation of our basic model. There are two sectors that produce durables: one with sticky prices and one with flexible prices. There are also two sectors that produce nondurables: one sticky and one flexible. This allows us to vary the fraction of durable goods with sticky prices without changing the total fraction of goods that are durable.

\footnotetext{
${ }^{24}$ Because we are changing the share of durables in GDP and because the production of durables is inherently more volatile than for nondurables, we normalized the lines by the response when all of GDP consists of either the durable or the nondurable good. The non-normalized graph looks similar.
} 
Because small deviations in the relative price of the durable goods will usher forth very large swings in production of the two durable goods, we restrict the extent to which labor can move across sectors. To do this we assume that the disutility of leisure is given by:

$$
v\left(n_{c 1}, n_{c 2}, n_{d 1}, n_{d 2}\right)=\frac{\left(\phi_{1}^{c}\right)^{\frac{\eta}{\eta+\xi}}}{1+\frac{1}{\eta}}\left[\left\{\left(n_{1 t}^{c}\right)^{\frac{\eta+\xi}{\eta}}+\frac{\phi_{2}^{c}}{\phi_{1}^{c}}\left(n_{2 t}^{c}\right)^{\frac{\eta+\xi}{\eta}}+\frac{\phi_{1}^{d}}{\phi_{1}^{c}}\left(n_{1 t}^{d}\right)^{\frac{\eta+\xi}{\eta}}+\frac{\phi_{2}^{d}}{\phi_{1}^{c}}\left(n_{2 t}^{d}\right)^{\frac{\eta+\xi}{\eta}}\right\}^{\frac{\eta}{\eta+\xi}}\right]^{1+\frac{1}{\eta}}
$$

Here, the ratios, $\phi_{i}^{j} / \phi_{1}^{c}$ govern the ratio of production of sector $i, j$ where $i=1,2$ indicates whether the sector has flexible prices or sticky prices and $j=c, d$ indicates whether the good is a nondurable $(c)$ or a durable $(d)$ (the remaining free parameter $\phi_{1}^{c}$ is normalized so that aggregate employment $N_{t}=\sum_{i, j} n_{i}^{j}=1$ in the steady state). The aggregate elasticity of labor supply is controlled by $\eta$ while the degree to which labor can move across sectors is controlled by $\zeta$. If $\zeta=0$ then labor is completely mobile across the sectors. As $\zeta$ increases, the extent to which labor can freely flow from one sector to the next is inhibited. When $\zeta=1$, labor supply is additively separable across sectors and the sectors are fully insulated from each other. In the limit as $\mu \rightarrow \infty$, no sector can expand unless the others also expand.

Figure 6 graphs the first quarter responses of aggregate output (and employment) to a permanent (1\%) increase in the money supply. The left-hand-side figures show what happens as we slowly change the fraction of durable goods that are sticky holding the fraction of sticky nondurables industries fixed. Each line represents a different fixed fraction of the nondurables industries with sticky prices (i.e. $25 \%$ means that $25 \%$ of nondurable consumption sectors have prices that are sticky). The right hand side figures show the same experiment as we vary the fraction of sticky price nondurable industries holding the fraction of sticky durables sectors fixed.

When $\zeta=.001$, there is a great deal of labor mobility across sectors. In this case, increasing the fraction of durable goods with sticky prices increases the first quarter increase in employment regardless of how many nondurables goods have sticky prices. In contrast, increasing the fraction of nondurable goods with sticky prices does not 
contribute as much to the change in employment. With $\zeta=.001$, the response of employment depends heavily on the fraction of durable goods with sticky prices.

For higher values of $\zeta$ (so that labor is less mobile) the fraction of nondurables with sticky prices is more and more important. Because labor cannot easily flow from one sector to another, increased production in sticky price industries is achieved by extending the hours of workers in that sector. When $\zeta=1$, if all durable goods have flexible prices while all nondurables have sticky prices then employment rises by $.6 \%$ in the first quarter; this is roughly $75 \%$ of the first quarter response when all goods had sticky prices in the standard New Keynesian model. Note that when there isn't much price rigidity in the nondurable industries (say less than $25 \%$ of the nondurables have sticky prices), having some rigidity in the durables industries is very important. Even though the durables sectors are a relatively small part of GDP, they are a very important determinant of aggregate dynamics.

Finally, figure 7 shows the first quarter response of employment in the model with flexible durables prices as we vary the rate at which the durable depreciates. As we would expect, when the good is more long-lived, the stock/flow distinction is sharper and our neutrality approximation works well. If the depreciation rate is .03 per year (which is comparable to the depreciation rate for houses), employment increases by less that $5 / 100$ ths of a percent in the quarter following the shock. On the other hand, if the depreciation rate is .50 per year then the first quarter employment response is greater than $0.25 \%$.

\section{Resolving the Comovement Problem:}

The comovement problem is a consequence of equation (4.1). This equation equates the supply and demand for labor in an industry that produces durable goods with flexible prices. There are two basic ways to resolving the comovement problem. One way would be to assume that there are forces that influence the demand $(\gamma)$ or the supply $(v$ ' and $M P^{N}$ ) of durables. Alternatively, it could be that equation (4.1) simply does not hold. In this section, we consider some natural modifications to our model and ask whether they might be part of a solution to eliminate negative comovement. 


\section{$\underline{\text { Immobile Labor }}$}

One feature of the model above is that labor is homogeneous and can move freely across sectors. This means that there is one aggregate labor supply curve governed by $v^{\prime}\left(N_{t}\right)$. If aggregate employment rises then costs will rise in durables sector. This argument does not work when there are separate labor supply curves for each industry. Industry-specific labor supply curves insulate sectors from rising costs in other areas of the economy and as a result might be important in mitigating the co-movement problem.

Consider a modification of the model to allow for separate labor supply relationships. Utility is given by:

$$
U=E\left(\sum_{t=0}^{\infty} \beta^{t}\left[u\left(c_{1 t}, c_{2 t} \ldots, c_{j t}, \ldots d_{1 t}, d_{2 t}, \ldots d_{j t} \ldots\right)-\Phi\left(\left\{N_{j t}\right\}_{j}\right)\right]\right)
$$

where $N_{j t}$ is labor supplied in sector $j$ at time $t$ and $\Phi$ is an aggregator. Previously we assumed that $\Phi$ was simply a convex function $v($.$) of the sum of the N_{j t}$. To keep things simple take $\Phi$ to be a sum of convex functions $\Phi=\sum_{j} v_{j}\left(N_{j t}\right)$. This effectively isolates each sector's labor supply pool (there is no substitution of labor at all across the industries).

Now, increased employment in other sectors during a monetary expansion will drive up the cost of producing only those goods. The pressure on labor markets in other sectors will have no affect on the supply of labor in flexible price sectors. The labor market clearing condition in a durable sector with flexible prices is now:

$$
v_{j}^{\prime}\left(N_{j t}\right)=w_{j t} \frac{\gamma_{j t}}{P_{j t}}=\frac{M P_{j}^{N}\left(N_{j t}\right)}{\mu_{j}} \gamma_{j}
$$

where the second equality again follows from durability (resulting in a constant marginal utility $\gamma_{j}$ ) and price flexibility (giving the constant markup $\mu_{j}$ ). This is one equation in the one unknown $N_{j t}$. Thus, in the extreme case of no labor mobility at all across sectors, durable goods with flexible prices will not respond at all to monetary shocks. To the 
extent that there is any labor mobility across sectors, durable goods sectors with flexible prices will contract after a monetary expansion.

When factors are totally bound to one sector or another, durable goods sectors will not vary with the business cycle. Thus, although frictions in labor reallocation help to alleviate the co-movement problem, they cannot solve it. The best this modification can do is to render the durables sector acyclical.

\section{Complementarities.}

Complementarities and externalities can influence demand and/or costs. To the extent that the sticky price sectors increase production following a monetary expansion, positive spillovers may increase the demand for durables sufficiently to resolve the comovement problem. If the marginal utility of durable consumption rises with increases in the consumption of nondurables then $\gamma$ will rise with the expansion of production in the nondurables sector.

While a high degree of complementarity sounds promising on its face, there are two problems with this type of demand spillover. First, recall that $\gamma$ is the discounted sum of marginal contributions to utility from an acquiring an additional unit of the durable good:

$$
\gamma_{j t}=M U\left(d_{j t}, c_{i t}\right)+\beta(1-\delta) M U\left(d_{j t+1}, c_{i t+1}\right)+\beta^{2}(1-\delta)^{2} M U\left(d_{j t+2}, c_{i t+2}\right)+\ldots
$$

where we now allow for explicit dependence of the marginal utility on another consumption good (a nondurable) $c_{i t}$. Because monetary shocks raise production of nondurables temporarily, only the first few terms of this sum can be affected by the complementarity. Unless the complementarity is very strong, the percentage change in $\gamma$, and as a result, the increased incentive to produce additional durable goods, will be small.

Second, complementarities between durables and nondurables tie the consumption (and production) of nondurables to the stock of durable goods. If the stock of the durable cannot rise quickly, then, modest amounts of demand complementarities will reduce the incentive to produce the nondurable good. This is a side effect of a demand complementarity. While it can potentially reduce the degree of negative 
comovement in the durables sector, it also reduces the procyclicality of the associated nondurable sector.

Figure 8 shows three simulations of the benchmark model (with flexible durables prices). The top panel is our benchmark model. As we saw before, output does not change in response to monetary stimulus, durable goods production falls and nondurable production rises. The middle panel shows the same model with a high degree of complementarity between durable consumption and nondurable consumption. Specifically, we set the elasticity of substitution between durables and nondurables to $\rho=$ 0.1 . As before, output is still approximately neutral. Durable goods production does not fall by as much as it did before, while production of the nondurable still increases but by much less. The bottom panel shows an extreme case of complementarity. We set the elasticity of substitution between durables and nondurables to $\rho=0.01$. At this point, the comovement problem begins to go away. However, the neutrality that was previously confined to aggregate employment and GDP has now spread to each sector individually. Put differently, because the durable has a low depreciation rate, a high degree of complementarity strengthens the neutrality result.

Another form of complementarity arises if the durable is productive capital. If employment rises following a monetary expansion, the marginal product of capital also rises, which increases the demand for capital. The more aggregate employment responds to monetary shocks, the more this complementarity will stimulate investment spending. As with the previous form of demand spillover, this mechanism requires a significant and prolonged increase in employment. If monetary business cycles are short-lived, then, as before, the increased payoff to capital will be short-lived and $\gamma$ will rise only slightly.

Externalities and complementarities that lower costs of production have more potential to resolve the comovement problem than do demand spillovers. Labor supply complementarity is one example of such an effect. If labor supply and the consumption of nondurables are complementary, then increased production of nondurables, shifts out the labor supply curve, reducing costs. If this effect is strong enough, it could raise 
production in the durables sectors. ${ }^{25}$ In general, any spillover effect that lowers costs in the durables sector could potentially increase the production of durables. It is easier to argue that spillovers mitigate the comovement problem by lowering costs than to claim that they provide a rationale for increased demand for durables.

\section{$\underline{\text { Credit Constraints and the Financial Accelerator }}$}

The other way to attack the comovement problem is simply to consider models in which equation (4.1) does not hold. One way to break equation (4.1) is to assume that people who buy new houses are constrained in their ability to make purchases. For consumers who are credit constrained, $\gamma>P_{t}^{d} \lambda_{t}$ and as a result (4.1) is not an equality.

More specifically, suppose that the demand for durables is primarily composed of people who need to borrow to acquire the durable. Furthermore, assume that many of these people face binding borrowing constraints. These customers would like to borrow against their future income to buy more durable goods but they are up against their borrowing constraint. For these customers, $\gamma_{t}>\lambda_{t} P_{t}^{d}$. This breaks the link in the benchmark model between the marginal utility of an extra durable and its price. A model with this feature might not display the comovement problem. Assuming that income rises in the wake of a monetary shock, agents who face binding credit constraints may spend their additional income on durable goods even if nondurable goods become relatively cheaper.

Many models imply that the severity of borrowing constraints is inversely related to cash flow or collateral (the financial accelerator hypothesis). For example, an improvement in income or employment status can have a substantial effect on the size of the mortgage for which a buyer can qualify. Extra income plays two roles in such a model. In addition to the effect in the previous paragraph, additional income will also relax the borrowing constraint. Both of these effects make the demand for durables depend on income (GDP) rather than the aggregate stock of durables.

\footnotetext{
${ }^{25}$ If labor supply is complementary with the stock of durables then, because the stock of durables is roughly constant, aggregate employment will remain roughly constant. This may even reinforce the neutrality result and exacerbate the comovement problem.
} 


\section{Sticky Wages and Input Prices.}

When inputs into production have sticky prices, the final good will behave as though its price was somewhat sticky even if the final seller can set prices freely. ${ }^{26}$ This may be why some durables (and some nondurables) industries expand production in response to an increase in the money supply even if it is believed that their prices are completely flexible. The final price of new housing could be perfectly flexible but if wages of construction workers are sticky, then housing will still expand following a monetary expansion. If wages are sticky, then equation (4.1) does not hold. Workers are "off their labor supply curves" and as a result do not equate the marginal disutility of work to the marginal benefit of working more.

To make this point formally, we modify our two-sector model to allow for sticky wages. We follow Erceg, Henderson and Levin [2000] by modeling wage rigidity as a third Calvo process. Specifically, we assume that effective labor for the firms is an aggregate of labor "types". Specifically, if $L_{t}$ is effective labor at time $t$ we have:

$$
L_{t}=\left[\int_{0}^{1} l_{i t}^{\frac{\xi-1}{\xi}} d i\right]^{\frac{\xi}{\xi-1}}
$$

If firms hire $L_{t}$ units of effective labor then the demand for any individual labor type is:

$$
l_{i t}=L_{t}\left(\frac{w_{i t}}{W_{t}}\right)^{-\xi}
$$

where wages for each worker type are set by monopolists that seek to maximize the utility of the representative household taking the demand for their type as given. The aggregate wage is:

$$
W_{t}=\left[\int_{0}^{1} w_{i t}^{1-\xi} d i\right]^{\frac{1}{1-\xi}}
$$

Let $\theta_{w}$ be the probability that an arbitrary monopolist cannot reset the wage in any period. Then, arguments similar to those in the sticky price section give us a wage setting process that obeys:

$$
\tilde{w}_{t}^{*}=\left(1-\theta_{w} \beta\right)\left[\tilde{P}_{t}^{c}+\frac{1}{\eta} \tilde{N}_{t}-\left(\frac{1}{\rho}-\frac{1}{\sigma}\right) \tilde{U}_{t}+\frac{1}{\rho} \tilde{C}_{t}\right]+\theta_{w} \beta E_{t}\left[\tilde{w}_{t+1}^{*}\right]
$$

\footnotetext{
${ }^{26}$ Note that in the simulated models, we assume that the primary source of stickiness in the final goods prices does come from sticky intermediate goods prices.
} 


$$
\tilde{W}_{t}=\theta_{w} \tilde{W}_{t-1}+\left(1-\theta_{w}\right) \tilde{w}_{t}^{*}
$$

where $W_{t}$ is the aggregate wage rate and $w_{t}^{*}$ is the optimal "reset wage" for unions that have the opportunity to change their wage rate.

Figure 9.a shows the impulse response function for the two sector model to a permanent $1 \%$ increase in the money supply under the assumption that wages are reset on average once per quarter. The comovement problem is greatly mitigated; in the first quarter durable goods production rises by $1.97 \%$. Still, durable goods production remains below its benchmark level for the year. In quarters two, three and four, the production of durables is below steady state by $-0.29 \%,-1.00 \%$, and $-1.02 \%$ respectively. Figure $9 . \mathrm{b}$ shows the same model under the assumption that wages are reset on average once every six months. ${ }^{27}$ The comovement problem is now essentially gone. Durable goods production is above trend in the first two quarters by $2.8 \%$ and $1.3 \%$ respectively. It does fall below trend in the fourth quarter but only by $0.08 \%$. The assumption that wages are reset only once every six months does not sound like an implausibly high degree of wage rigidity. If wages are at least this rigid then nominal wage rigidity might be a very important part of a resolution to the comovement problem.

\section{Conclusion}

Sticky price models exhibit strongly counterfactual behavior when they include markets for durable goods with flexible prices. Consumers care about the stock of durable goods rather than the flow of purchases. Because the timing and magnitude of durables purchases can be varied considerably without noticeable changes in the stock, purchases of durable goods have an inherently high intertemporal elasticity of substitution. When the economy expands, marginal costs rise throughout the economy. Firms that have sticky prices simply produce to meet demand for their products. However, in the absence of offsetting increases in demand for their products, firms with flexible prices respond to the higher marginal cost by reducing production. High marginal cost combined with a

\footnotetext{
${ }^{27}$ This is still less rigidity than our benchmark setting for price rigidity; a six month half life corresponds to resetting prices, on average, roughly 1.4 times per year.
} 
readiness to bunch the production and purchase of durables means that when the rest of the economy expands, durable goods sectors with flexible prices should contract.

Sticky price models do not exhibit sufficiently powerful cyclical effects on the desired stock of durables to offset the very strong tendency for agents to substitute purchases over time. Standard sticky price models require significant additional features if they are to permit durables with flexible prices and still match the central features of the data. To this end, wage rigidity and borrowing constraints may be valuable features to add to existing models. 


\section{References:}

Ball, Laurence and Romer, David. "Real Rigidities and the Non-Neutrality of Money." Review of Economic Studies 57, April 1990: 183-203.

Basu, Susanto and Fernald, John. "Aggregate Productivity and the Productivity of Aggregates.” NBER working paper \# 5382, December 1995

Bernanke, Ben S. and Mihov, Ilian. "Measuring Monetary Policy." Quarterly Journal of Economics, 113 (3), August 1998, 869-902.

Bils, Mark, "Pricing in a Customer Market," Quarterly Journal of Economics, November 1989.

Bils, Mark and Klenow, Peter. "Some Evidence on the Importance of Sticky Prices." NBER working paper \#9069, 2002

Bils, Mark, Klenow, Peter, and Kryvstov, Oleksiy. "Sticky Prices and Monetary Policy Shocks." Federal Reserve Bank of Minneapolis Quarterly Review, 27 \#1, winter, 2003.

Blinder, Alan and Mankiw, N. Gregory. "Aggregation and Stabilization Policy in a Multi-Contract Economy”, Journal of Monetary Economics 13, January 1984, 67-86

Chari, V.V.; Kehoe, Patrick and McGrattan, Ellen, "Sticky Price Models of the Business Cycle: Can the Contract Multiplier Solve the Persistence Problem?" Econometrica 68, no. 5 (September 2000): 1151-1179.

Doyle, Brian and Faust, John. "Three Dummies and the Stock Market.” Working paper, Federal Reserve Board, International Finance Division.

Erceg, Christopher; Henderson, Dale, and Levin, Andrew. “Optimal Monetary Policy with Staggered Wage and Price Contracts." Journal of Monetary Economics, 46 (2), October 2000, 281-313.

Erceg, Christopher and Levin, Andrew. "Optimal Monetary Policy with Durable and Nondurable Goods.” Federal Reserve Board working paper, April 2003.

Hulten, C. and F. Wykoff, Economic Depreciation of the U.S. Capital Stock. Report submitted to the U.S. Department of Treasury, Office of Tax Analysis, 1979.

Hulten, C. and F. Wykoff, "The Measurement of Economic Depreciation", in Depreciation, Inflation and the Taxation of Income from Capital, C. Hulten (ed.), Urban Institute, 1981.

Kimball, Miles, "The Quantitative Analytics of the Basic Neomonetarist Model." Journal of Money, Credit, and Banking, 27(4), 1995 Part 2, 1241-1277. 
Leahy, John. "Comment on The Effects of Real and Monetary Shocks in a Business Cycle Model with Some Sticky Prices." Journal of Money, Credit and Banking, v 27, n 4, Nov. 1995 part II.

Levy, Daniel and Young, Andrew. “'The Real Thing:' Nominal Price Rigidity of the Nickel Coke, 1886-1959.” unpublished manuscript, Emory University, 2002.

Mankiw, N. Gregory. "Hall's Consumption Hypothesis and Durable Goods." Journal of Monetary Economics 10, Nov. 1982, 417-426.

Murphy, Kevin M.; Shleifer, Andrei and Vishny, Robert. "Building Blocks of Market Clearing Business Cycle Models." NBER Working Paper. June 1989

Ohanian, Lee and Stockman, Alan. "Short-Run Effects of Money when some Prices are Sticky." Federal Reserve Bank of Richmond Economic Quarterly, v 80, n 3, Summer 1994.

Ohanian, Lee; Stockman, Alan and Killian, Lutz. "The Effects of Real and Monetary Shocks in a Business Cycle Model with Some Sticky Prices." Journal of Money, Credit and Banking, v 27, n 4, Nov. 1995 part II.

Romer, Christina and Romer David. "Does Monetary Policy Matter? A New Test in the Spirit of Friedman and Schwartz" NBER Macroeconomics Annual 4, 1989: 121-170.

Sargent, Thomas, J. Macroeconomic Theory, $2^{\text {nd }}$ ed. Academic Press, 1987.

Shapiro, Matthew. "Federal Reserve Policy: Cause and Effect." in Monetary Policy, N. G. Mankiw ed. 1994, University of Chicago Press.

Tobin, James. “A Dynamic Aggregative Model.” Journal of Political Economy, 1955.

Zbaracki, Mark; Ritson, Mark; Levy, Daniel; Dutta, Shantanu and Bergen, Mark. "Managerial and Customer Dimensions of Cost of Changing Prices: Direct Evidence from Industrial Markets." Working paper. 2002. 


\begin{tabular}{l|c|c|c|c|c|c|c|c|c|c|c|c|}
\hline Inflation & \multicolumn{10}{c}{$k^{\text {th }}$ Order Autocorrelation: } \\
\hline Lag $k$ : & 1 & 2 & 3 & 4 & 5 & 6 & 7 & 8 & 9 & 10 & 11 & 12 \\
\hline CPI & 0.73 & 0.69 & 0.71 & 0.60 & 0.55 & 0.51 & 0.45 & 0.35 & 0.37 & 0.35 & 0.31 & 0.30 \\
Nondurables CPI & 0.41 & 0.46 & 0.46 & 0.32 & 0.28 & 0.26 & 0.23 & 0.08 & 0.14 & 0.09 & 0.08 & 0.05 \\
Durables CPI & 0.66 & 0.58 & 0.64 & 0.49 & 0.46 & 0.50 & 0.41 & 0.39 & 0.45 & 0.35 & 0.33 & 0.31 \\
Automobiles CPI & 0.26 & 0.19 & 0.14 & 0.25 & 0.31 & 0.14 & 0.15 & 0.17 & 0.21 & 0.20 & 0.11 & 0.04 \\
Avg House Price & -0.37 & 0.21 & -0.08 & 0.04 & 0.12 & 0.02 & 0.02 & 0.00 & 0.08 & 0.05 & 0.01 & -0.06 \\
Med House Price & -0.37 & 0.09 & 0.06 & 0.05 & -0.01 & 0.01 & 0.05 & -0.04 & 0.02 & 0.06 & -0.07 & 0.00 \\
\hline
\end{tabular}

$\underline{\text { Table } 1}$ 
Figure 1.a : Average Response of Real Production Following a Romer Date
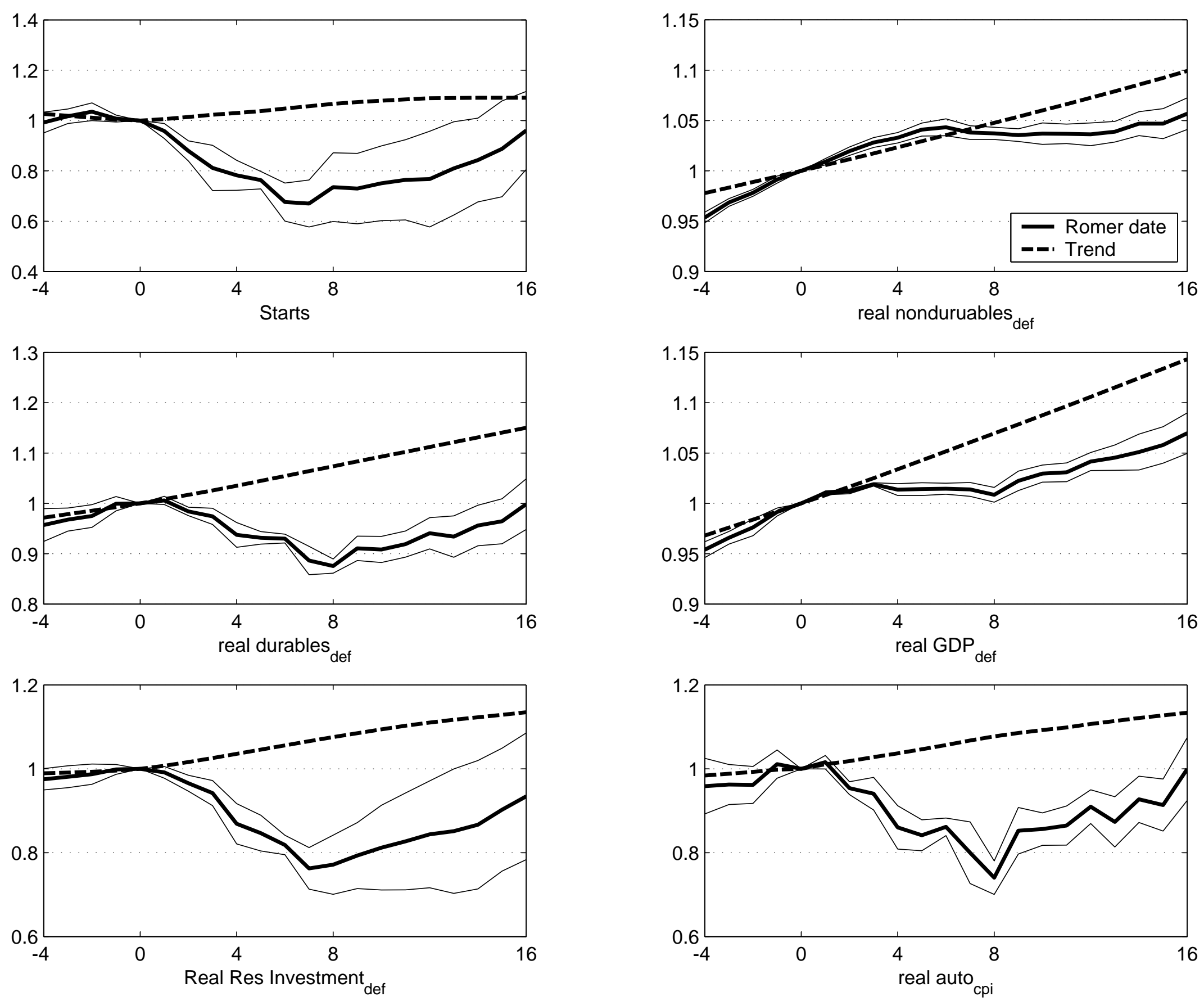
Figure 1.b : Average Response of Prices Following a Romer Date
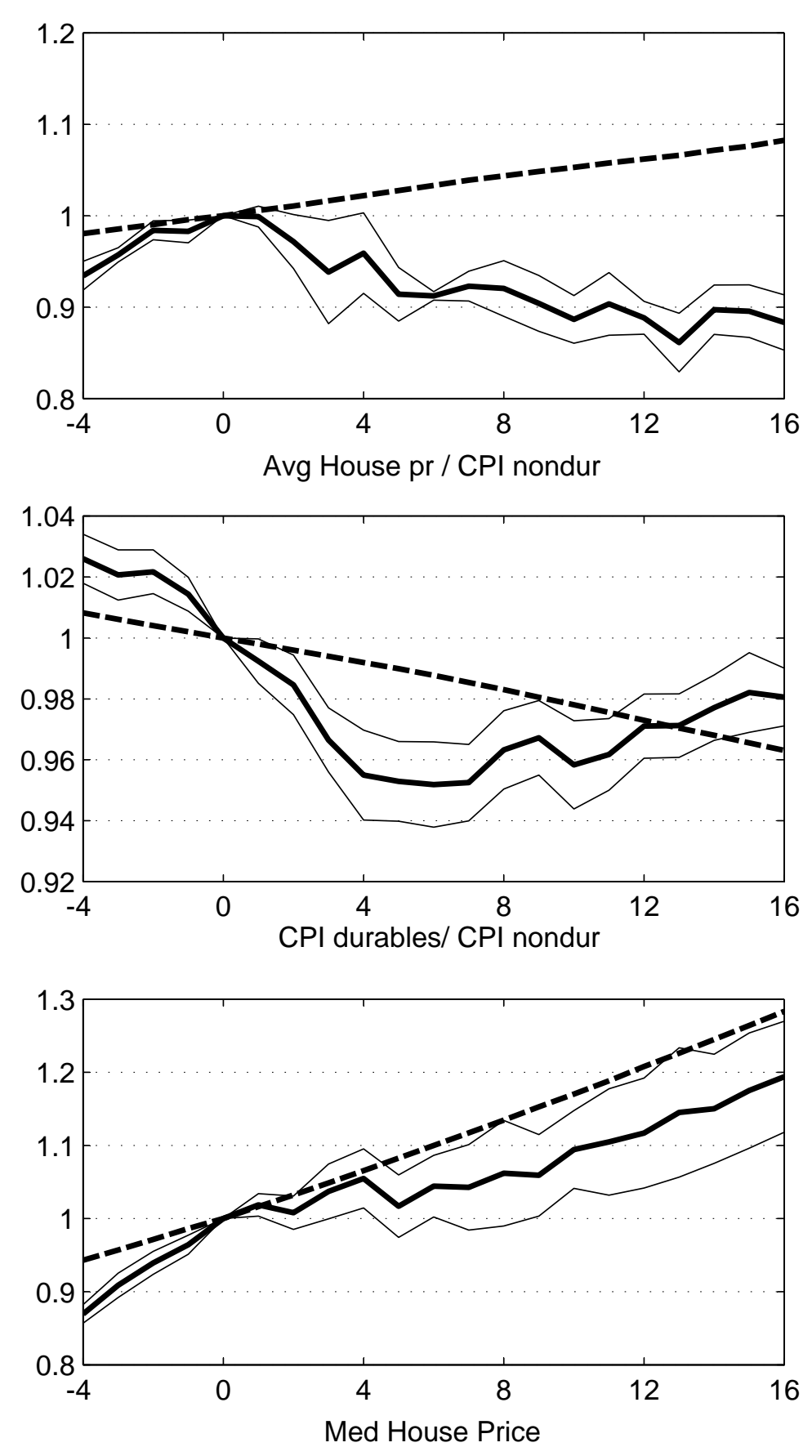
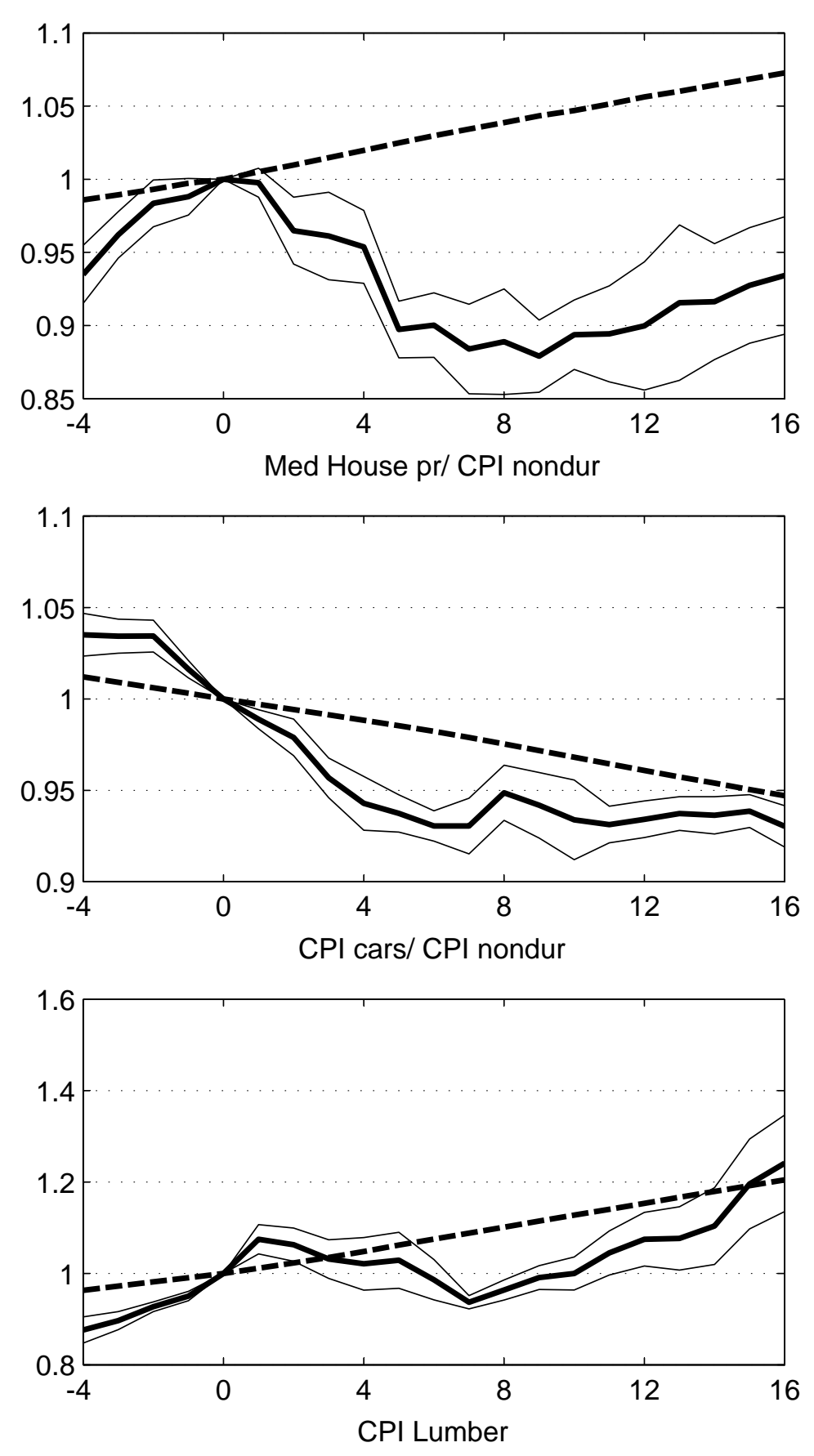
Figure 1.c : Average Response of Variables Following a Romer Date
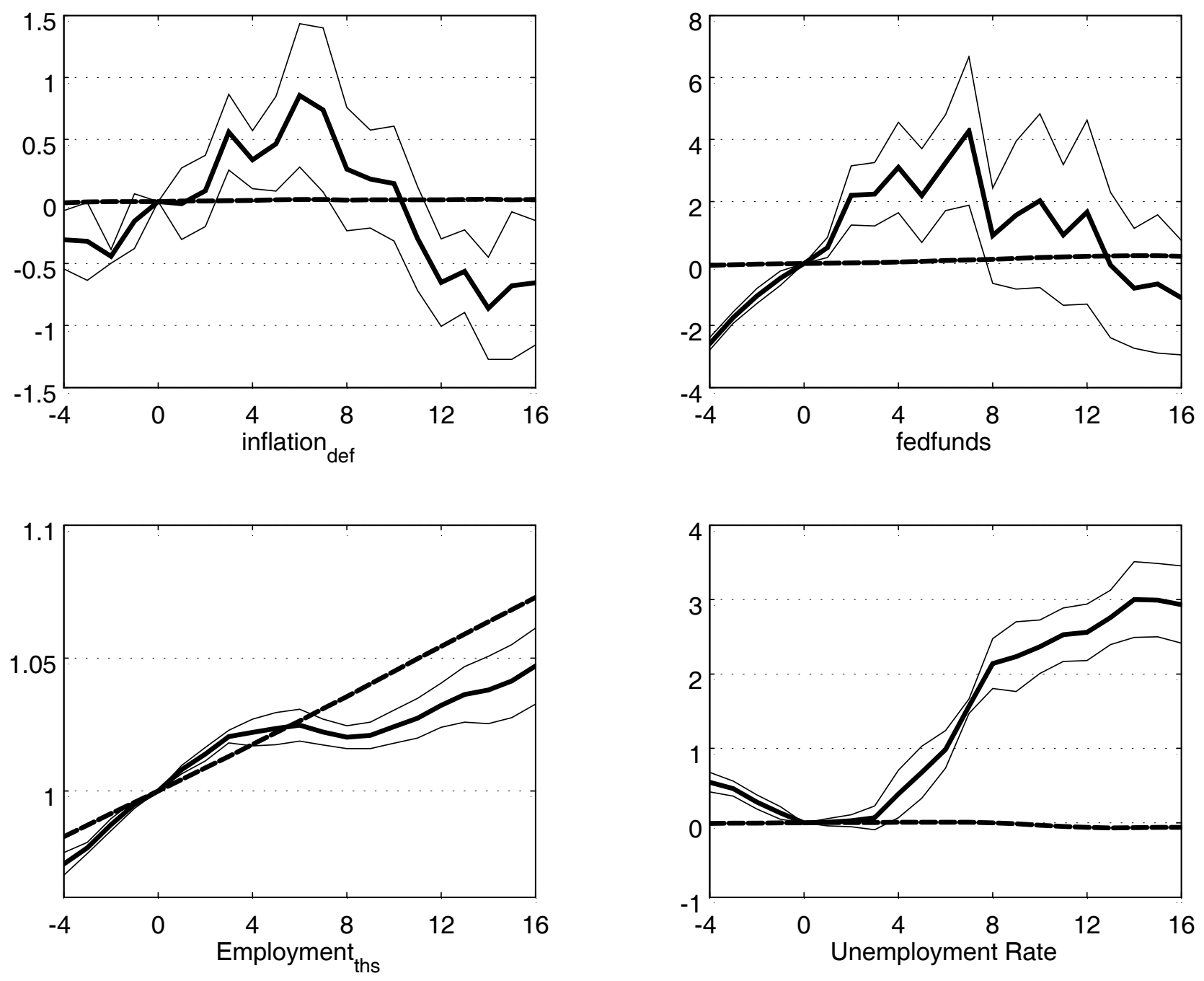
Figure 2.a: Symmetric Price Rigidity
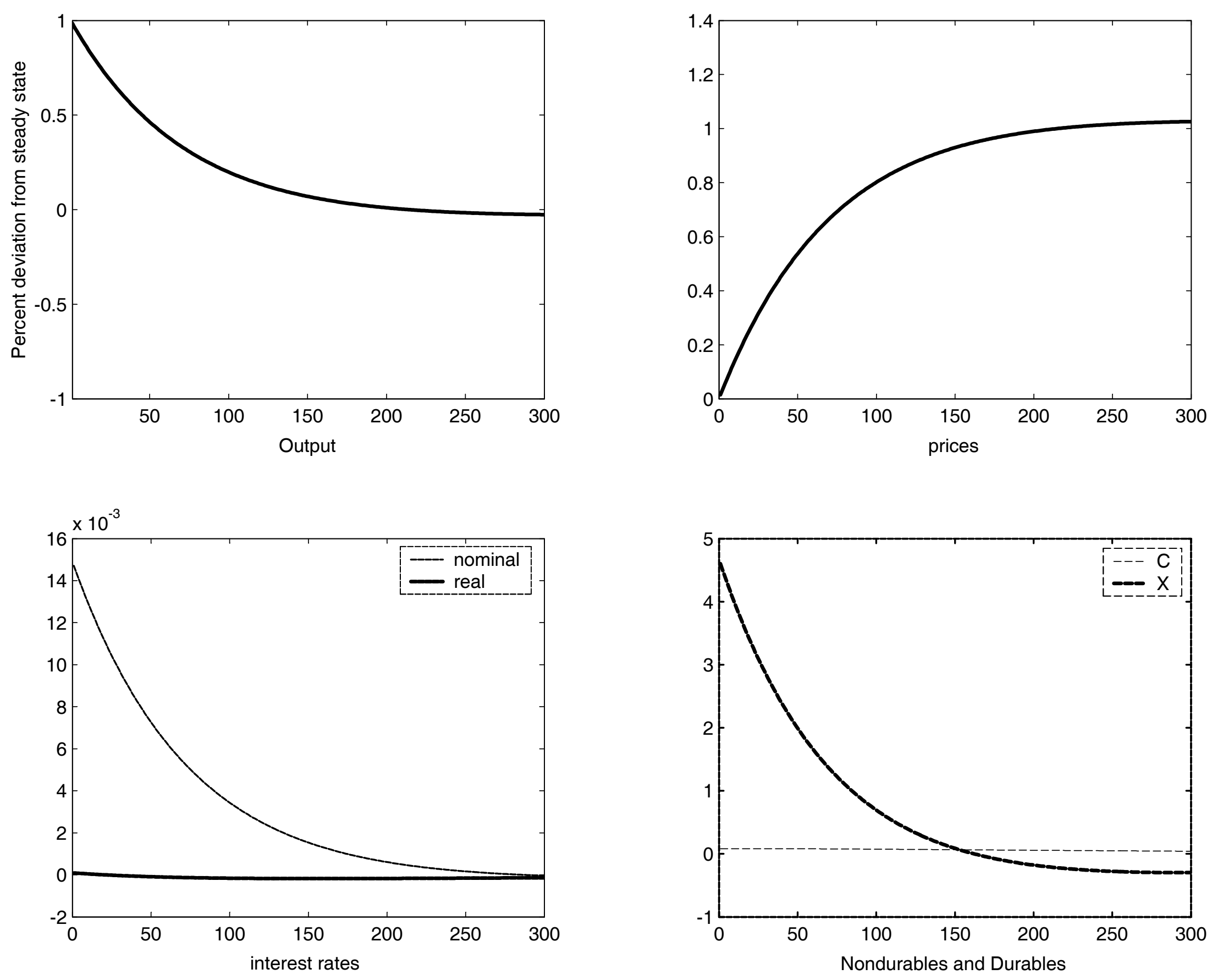
Figure 2.b: Sticky Prices and Nondurable Consumption Only
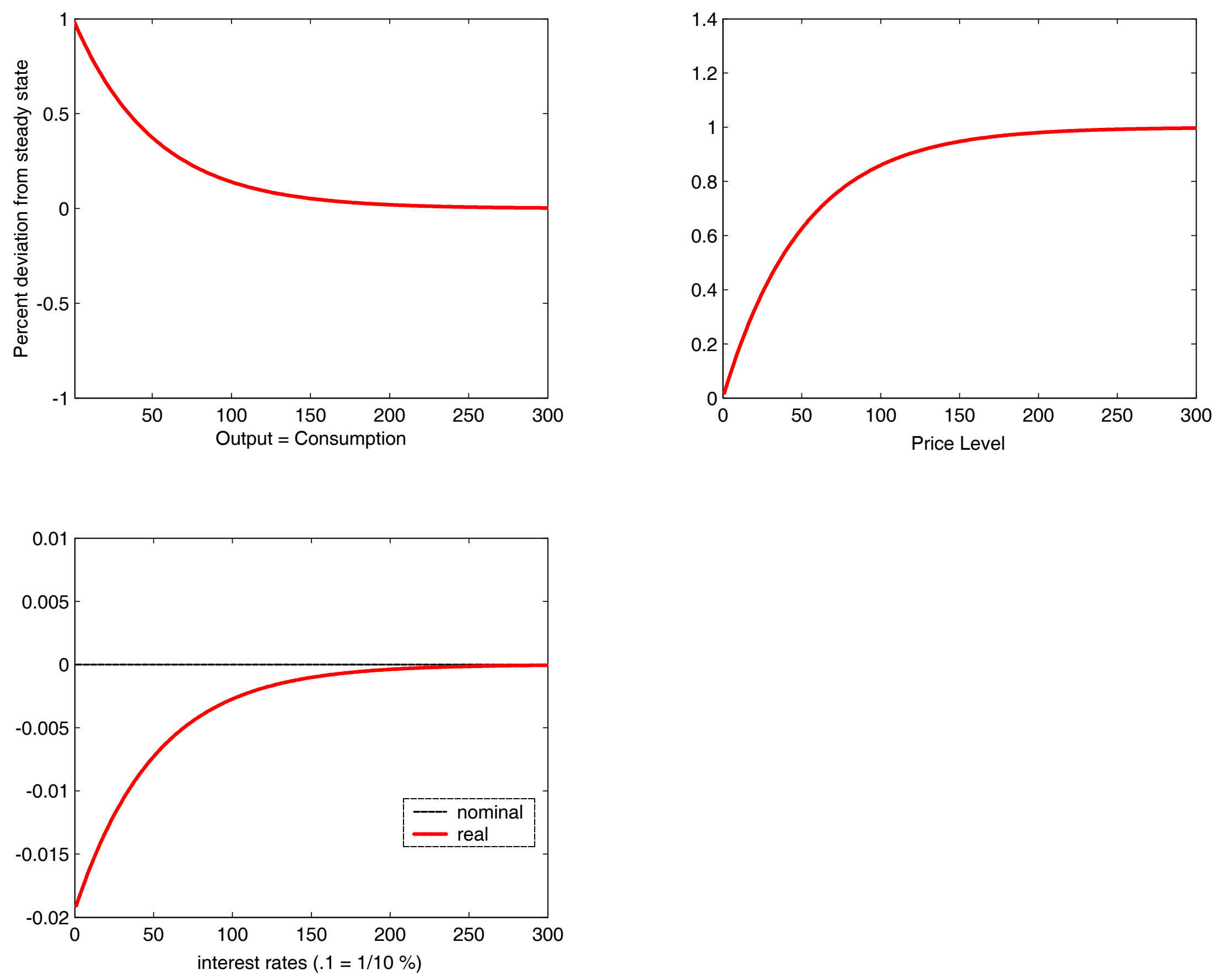
Figure 3: Sticky Non-Durables Prices and Flexible Durables Prices
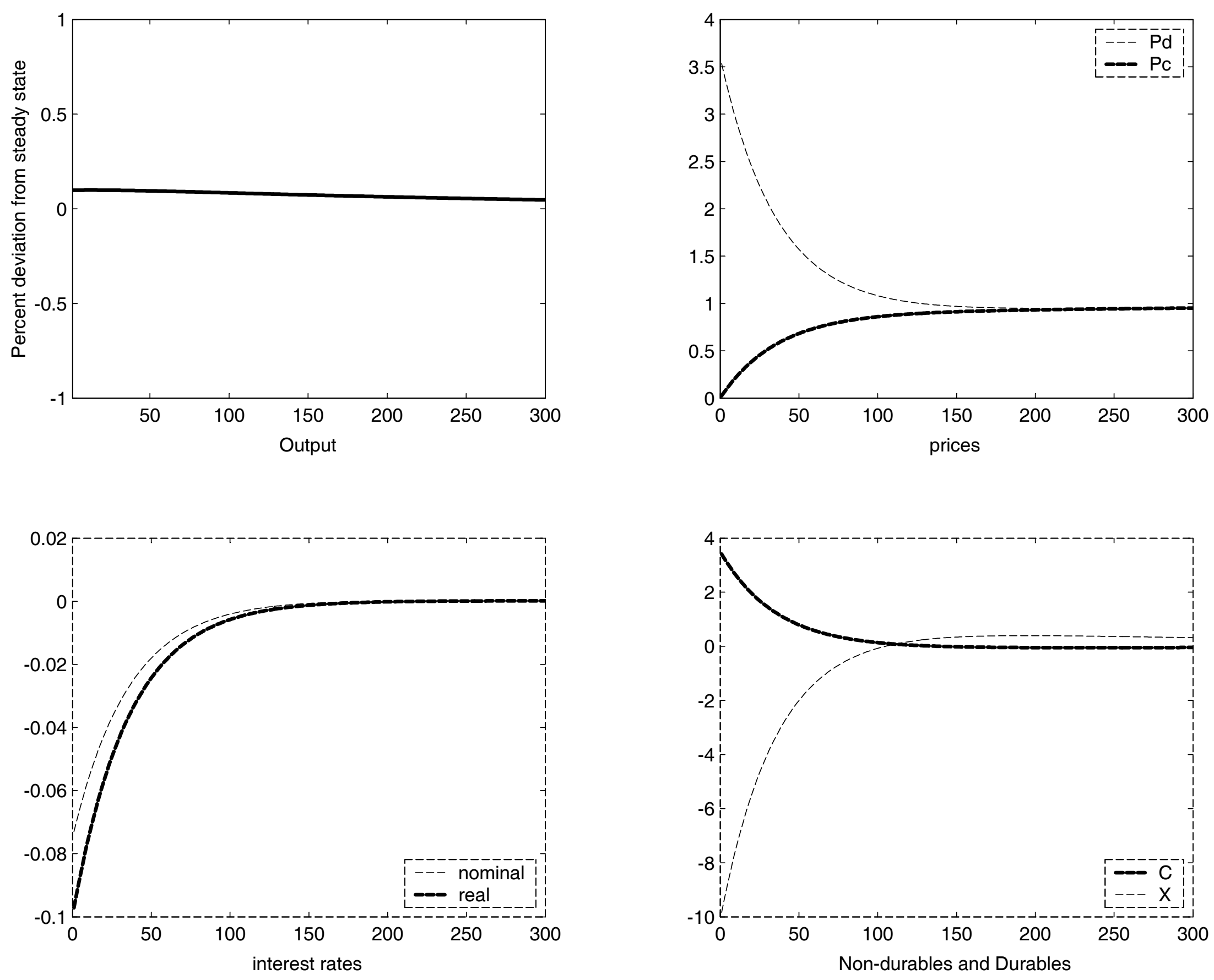
Figure 4: Sticky Durable Good Prices and Flexible Nondurable Prices
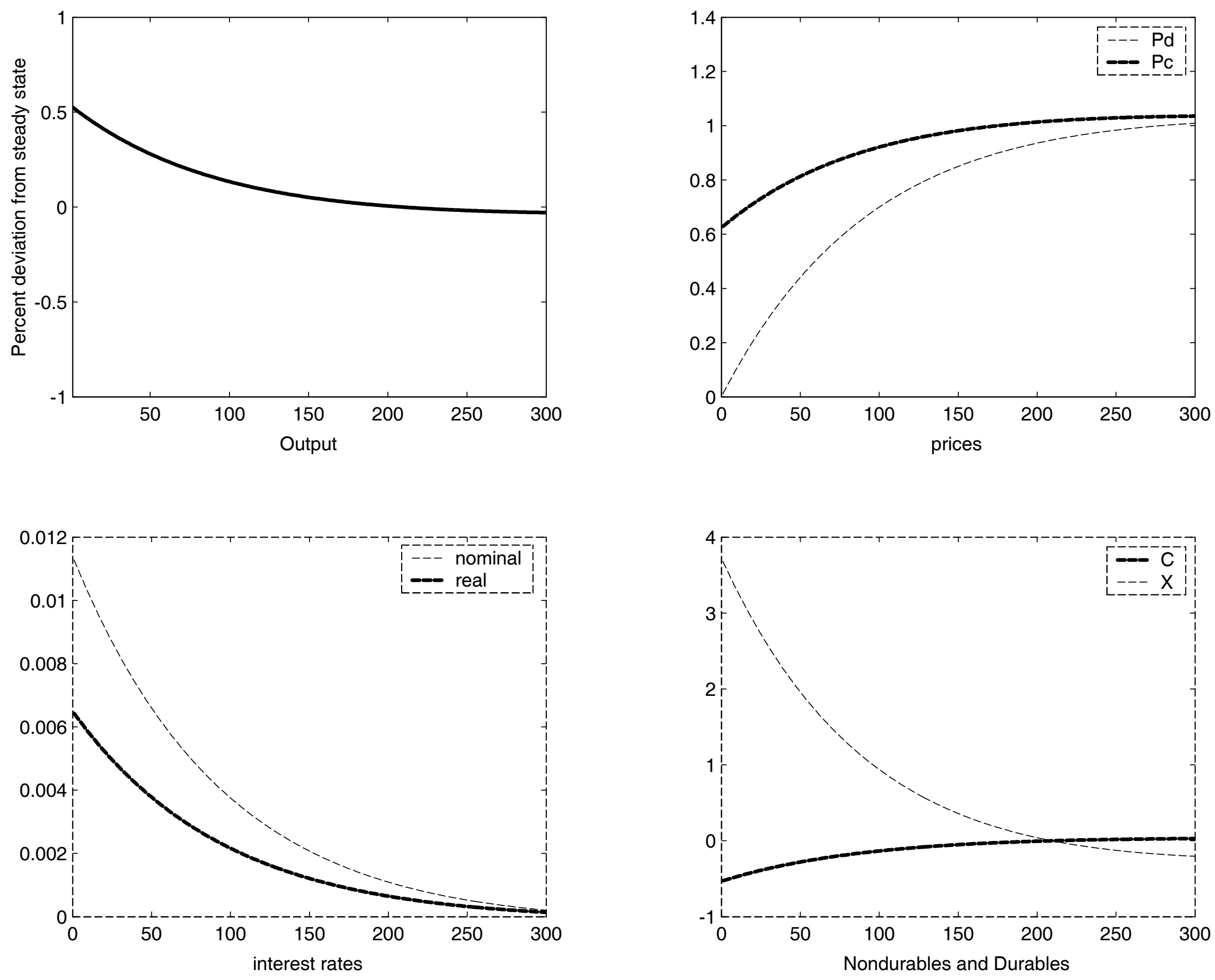
Figure 5: 1st Quarter Output Resposes for Different Models

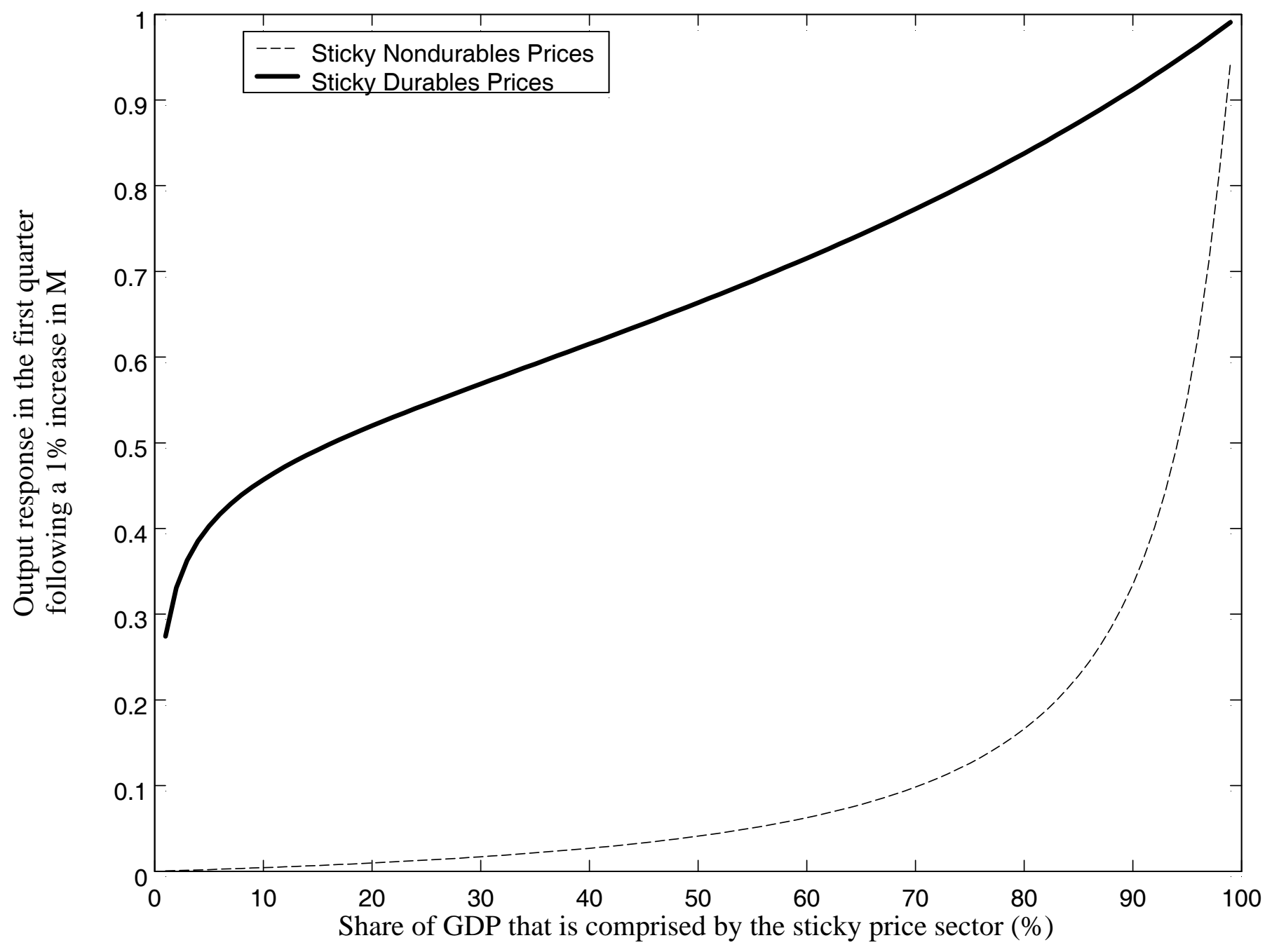


Figure 6: The First Quarter Increase in Employment As the Fraction of Goods with Sticky Prices Changes
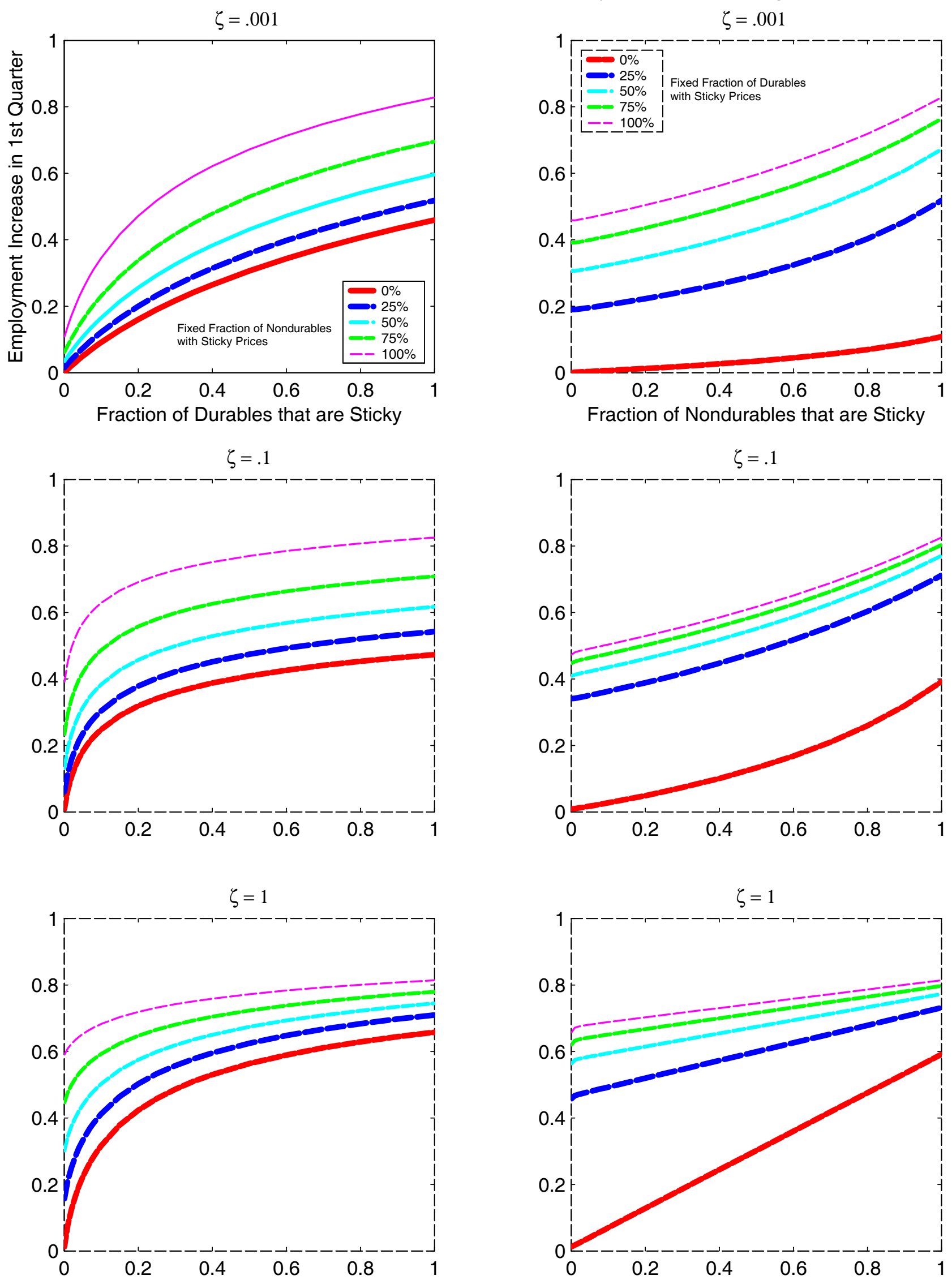
Figure 7: The First Quarter Increase in Employment as Durability Increases

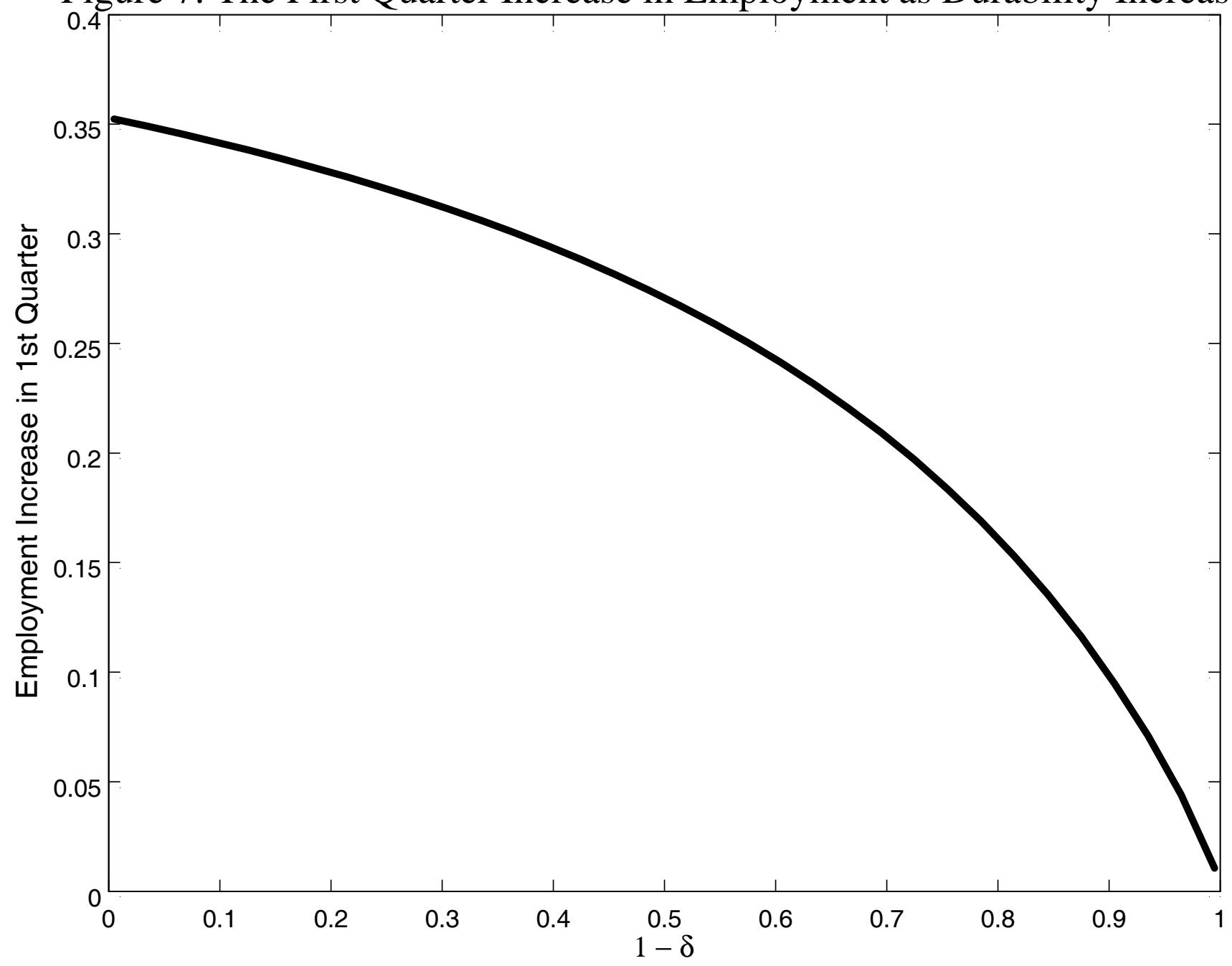


Figure 8 : Complementarity Between Durable and Nondurable Goods
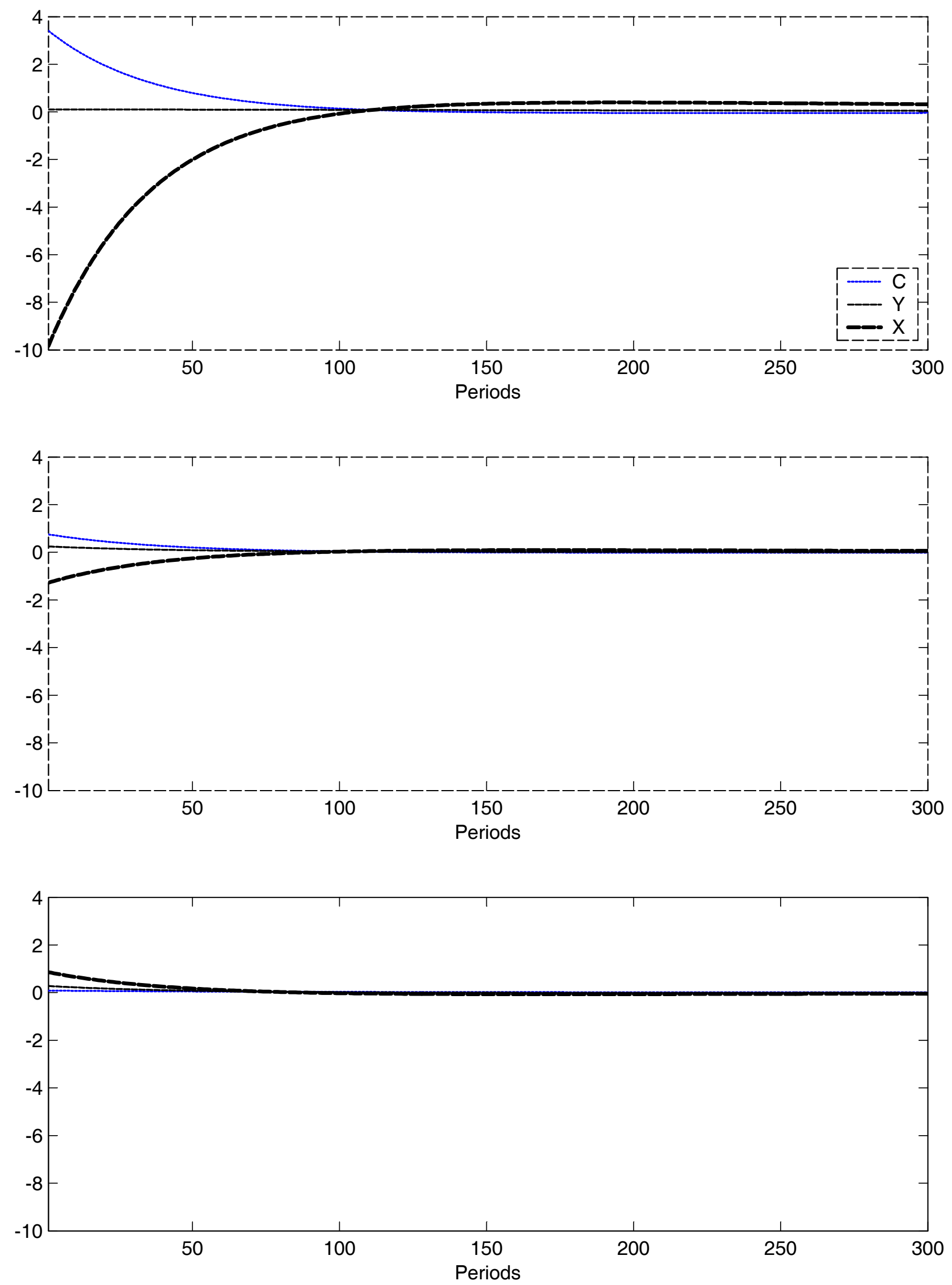
Figure 9.a : Sticky Wages and Flexible Durable Goods Prices
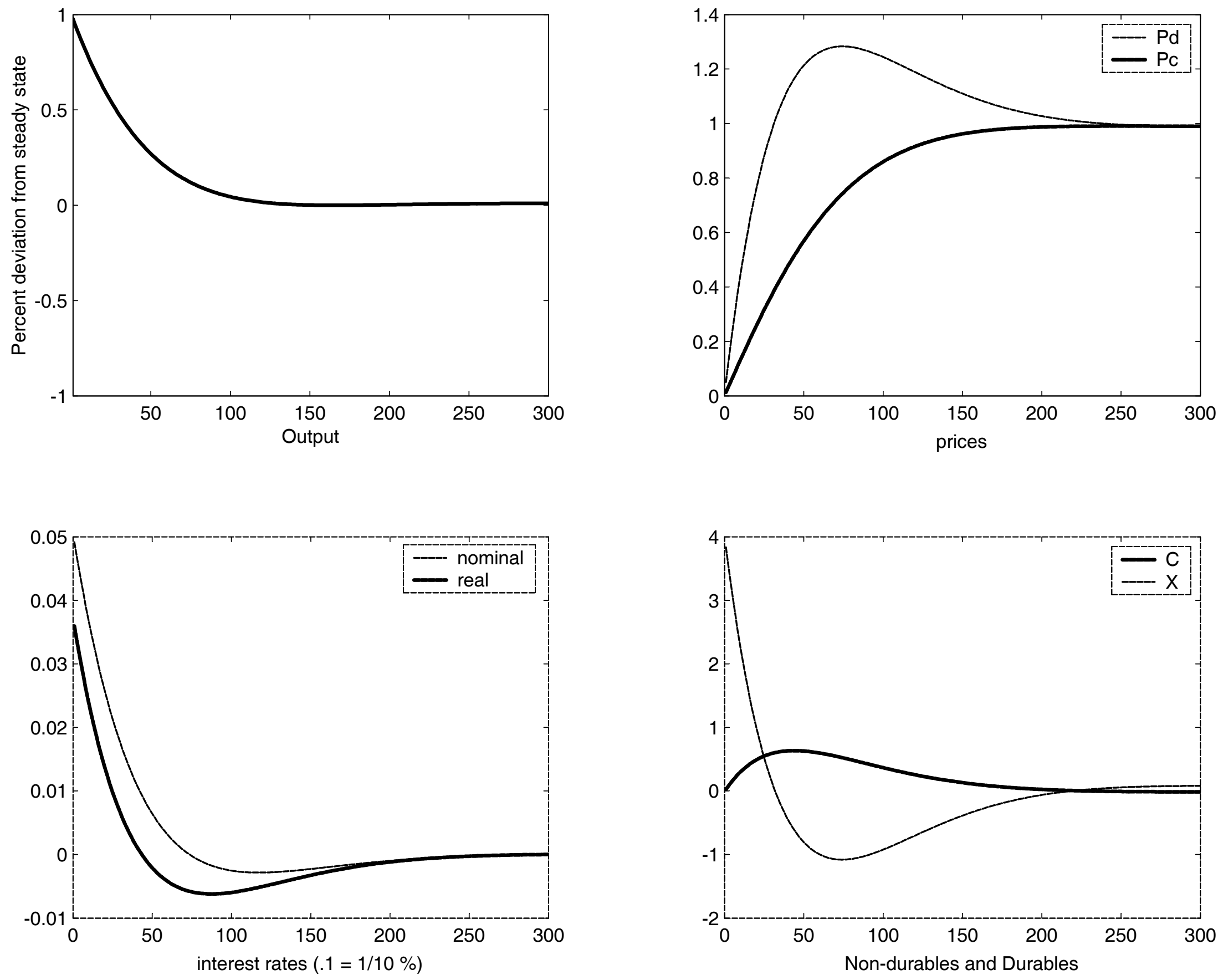
Figure 9.b : Sticky Wages and Flexible Durable Goods Prices
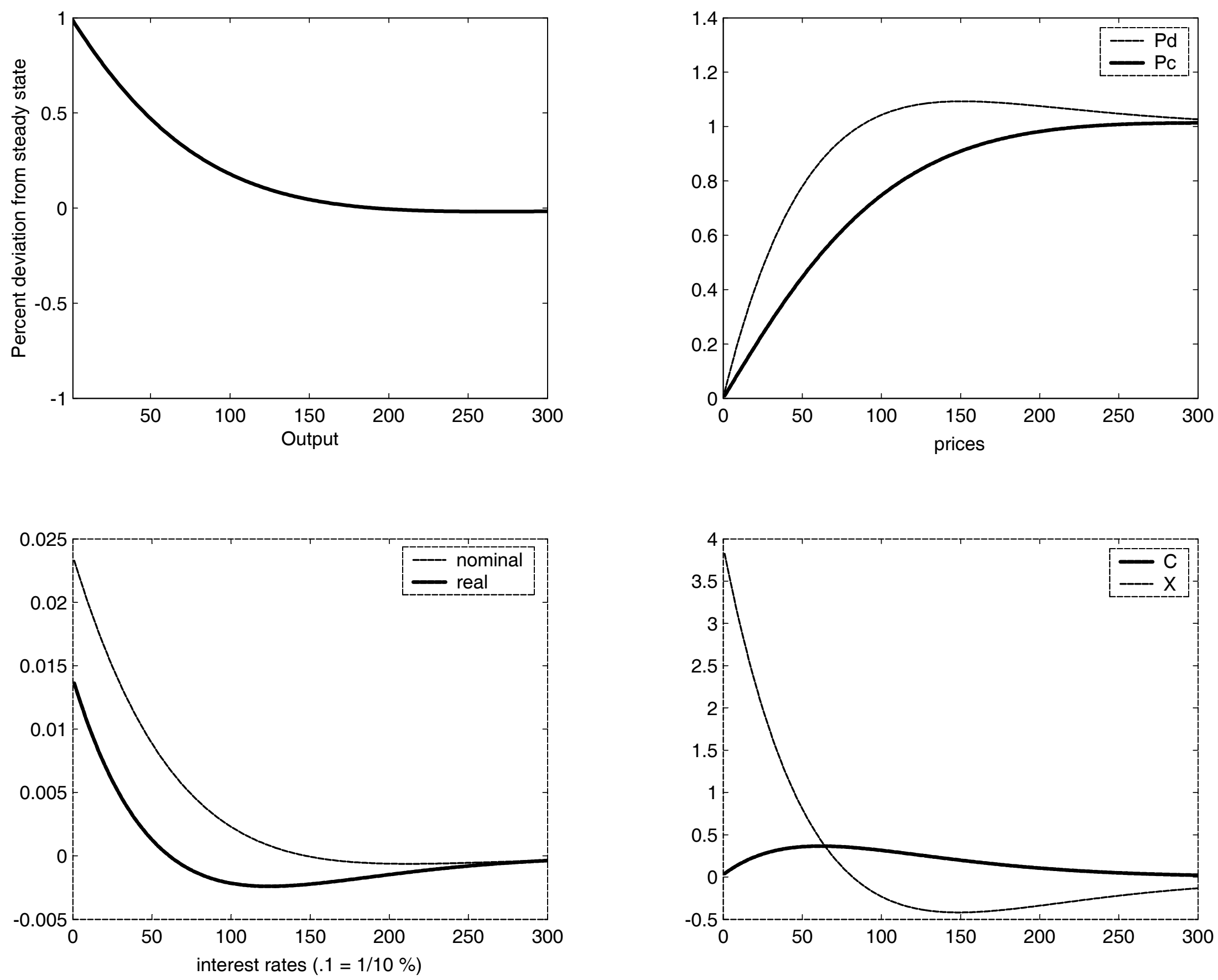

Non-durables and Durables 